\title{
IDŐJÁRÁS
}

Quarterly Journal of the Hungarian Meteorological Service

Vol. 125, No. 4, October-December, 2021, pp. 571-607

\section{Numerical simulations of June 7, 2020 convective precipitation over Slovakia using deterministic, probabilistic, and convection-permitting approaches}

\author{
André Simon ${ }^{1,2}{ }^{*}$, Martin Belluš $^{1}$, Katarína Čatlošová ${ }^{1}$, Mária Derková ${ }^{1}$, \\ Martin Dian ${ }^{1}$, Martin Imrišek ${ }^{1}$, Ján Kaňák ${ }^{1}$, Ladislav Méri ${ }^{1,3}$, \\ Michal Neštiak ${ }^{1}$ and Jozef Vivoda ${ }^{1,3}$ \\ ${ }^{1}$ Slovak Hydrometeorological Institute \\ Jeséniova 17, 85107 Bratislava, Slovakia \\ ${ }^{2}$ Hungarian Meteorological Service \\ Kitaibel Pál u. 1, 1024 Budapest, Hungary \\ ${ }^{3}$ Department of Astronomy, Physics of the Earth, and Meteorology \\ Comenius University in Bratislava \\ Mlynská Dolina, 84248 Bratislava, Slovakia
}

*Corresponding authorE-mail: andre.simon@shmu.sk

(Manuscript received in final form July 30, 2021)

\begin{abstract}
The paper presented is dedicated to the evaluation of the influence of various improvements to the numerical weather prediction (NWP) systems exploited at the Slovak Hydrometeorological Institute (SHMÚ). The impact was illustrated in a case study with multicell thunderstorms and the results were confronted with the reference analyses from the INCA nowcasting system, regional radar reflectivity data, and METEOSAT satellite imagery.

The convective cells evolution was diagnosed in non-hydrostatic dynamics experiments to study weak mesoscale vortices and updrafts. The growth of simulated clouds and evolution of the temperature at their top were compared with the brightness temperature analyzed from satellite imagery. The results obtained indicated the potential for modeling and diagnostics of small-scale structures within the convective cloudiness, which could be related to severe weather.

Furthermore, the non-hydrostatic dynamics experiments related to the stability and performance improvement of the time scheme led to the formulation of a new approach to linear operator definition for semi-implicit scheme (in text referred as NHHY). We demonstrate that the execution efficiency has improved by more than $20 \%$.
\end{abstract}


The exploitation of several high resolution measurement types in data assimilation contributed to more precise position of predicted patterns and precipitation representation in the case study. The non-hydrostatic dynamics provided more detailed structures. On the other hand, the potential of a single deterministic forecast of prefrontal heavy precipitation was not as high as provided by the ensemble system. The prediction of a regional ensemble system A-LAEF (ALARO Limited Area Ensemble Forecast) enhanced the localization of precipitation patterns. Though, this was rather due to the simulation of uncertainty in the initial conditions and also because of the stochastic perturbation of physics tendencies. The various physical parameterization setups of A-LAEF members did not exhibit a systematic effect on precipitation forecast in the evaluated case. Moreover, the ensemble system allowed an estimation of uncertainty in a rapidly developing severe weather case, which was high even at very short range.

Key-words: numerical weather prediction, multicellular convection, convection-permitting modeling, GNSS ZTD (Global Navigation Satellite System - Zenith Total Delay) data assimilation, radial Doppler wind assimilation, probabilistic forecasting, mesovortex, cloud top temperature

\section{Introduction}

The history of NWP (numerical weather prediction) activities at SHMÚ is manifold, concerning research and development in the field of data assimilation, dynamics, physical parameterization, predictability as well as diagnostics (Derková, 2005). These were mostly focused on forecasting mesoscale events, such as the downslope windstorm in High Tatras on November 19, 2004 (Simon et al., 2006). Arguably the most challenging task in mesoscale forecasting covers non-frontal thunderstorms, often accompanied by flash floods, hail, or other severe phenomena. A catastrophic flash flood in the year 1998 in the Malá Svinka basin (Svoboda and Pekárová, 1998) accelerated the endeavour to improve early diagnostics and prediction of such events. This resulted for example in local implementation and further development of the INCA nowcasting system (Haiden et al., 2011) in the frame of the FLOODMED and INCA-CE (Integrated Nowcasting Comprehensive Analysis - Central Europe) projects (Wang et al., 2017b).

Nevertheless, the possibility of nowcasting of local storms, which have basically multicellular character and undergo rapid development is very limited, when using only extrapolation methods. Early versions of the deterministic model at SHMÚ (called ALADIN/SHMU) were also not suitable for very short range forecasting in such cases, except for diagnostics of the convective environment. New opportunities were open after upgrading the physical parameterization of canonical model configuration ALARO (Termonia et al., 2018) and after further improvements in the non-hydrostatic dynamics, which involved the 
implementation of the iterative centered implicit (ICI) scheme (Bénard et al., 2010). In ALARO, it was the so-called 3MT package, including mesoscaleoriented parameterization of convection (Gerard, 2009) and microphysics (after Lopez, 2002), which enabled more realistic simulation of local convective events.

Data assimilation procedures that provide realistic initial state for NWP model integration are equally important to obtain the correct model forecast. At SHMÚ, firstly the spectral blending by digital filter method was applied to improve the large scale representation of the upper air fields (Derková and Belluš, 2007). Advanced variational data assimilation schemes are not operationally used at SHMÚ, mostly due to lack of computer resources. Recently there are several data assimilation activities based on 3D-Var approach ongoing in parallel: assimilation of the Mode-S data (Čatlošová and Derková, 2020), assimilation of zenith total delay observations (Imrišek et al., 2020), assimilation of Doppler weather radar measurements (Čatlošová, 2020) seemed to be promising in correcting the very short range forecasts at mesoscale, but these methods are still under development.

When forecasting severe mesoscale events, one has to deal with naturally large uncertainty already at nowcasting ranges or at very short lead times, which can be estimated with EPS (ensemble prediction system) methods. The SHMÚ EPS activities have been initiated in 2006 within the frame of the ALADIN-LAEF development, operational at the ECMWF HPCF (High-Performance Computing Facility) since 2011 (Wang et al., 2011). Currently, ALADIN-LAEF is being replaced by a more sophisticated system based on the ALARO model with substantially higher spatial and vertical resolution called A-LAEF (Belluš, 2020a). Up to now, several case studies on severe weather were performed showing the potential of this system to identify even local flash floods (e.g., the flood on August 17, 2019 in Turkey) or windstorms (Belluš, 2020b). The A-LAEF system became operational at ECMWF HPCF as a Time Critical 2 application in July 2020 , and its main objective is to provide reliable probabilistic forecasts at mesosynoptic scales for the national weather services of 8 RC LACE partners (Slovenia, Slovakia, Czech Republic, Croatia, Romania, Poland, Austria, Hungary) and Turkey.

The proper simulation of the initial conditions uncertainty as well as of the model uncertainty, together with the high-resolution physics well adapted to the local conditions, are crucial ingredients for the forecasting of convective events with generally low predictability. For this study a convective situation was chosen, which is rather typical in summer over Central Europe, and represents the above mentioned issues with forecasting non-organized, rapidly developing thunderstorms. Despite weak deep-layer shear and weak synoptic forcing, the thunderstorms on June 7, 2020 caused severe weather over Slovakia and the neighboring countries. It was mainly in the form of heavy precipitation or hail (ESWD, 2020) throughout the afternoon and evening hours. The operational ALADIN/SHMU forecasts used at that time predicted convective precipitation 
rather in association with a cold front arriving toward the end of the day. SHMÚ forecasters issued preliminary warnings on prefrontal thunderstorms already on June 5 and 6 but with the lowest level of severity. These were updated after the development of storms had begun, and the second level of warning (on intense thunderstorms with hail and high precipitation) was issued mainly for districts in the western part of Slovakia. Concerning the eastern part of Slovakia, likelihood of severe storms during night hours was indicated by the ESTOFEX (ESTOFEX, 2020). For these reasons it was examined, whether assimilation of new data and higher-resolution non-hydrostatic models are capable of improving the precipitation forecasts, and what the limits of deterministic forecasting are in these types of situations. The experiments were compared with pre-operational forecasts of the A-LAEF system and its respective members. The EPS outputs were also used to evaluate the predictability of the event and the possible impact of various physical parameterizations. Apart from precipitation, distinguishing between different types of convection (e.g., multicell or supercell-type) is an important ingredient for severe weather forecasting. Thus, the ability to forecast small-scale structures (e.g., mesocyclones) with the convection-permitting configuration of the ALARO model was tested and compared with available radar and satellite observations.

Similar activities are ongoing at other national meteorological services over Europe where convection-permitting NWP deterministic models (AROMEFrance, Seity et al., 2011; Brousseau et al., 2016; HARMONIE-AROME, Bengtsson et al., 2017; ALADIN at CHMI, Brožková et al., 2019; COSMO, Baldauf et al., 2011) as well as ensemble prediction systems (Arome-EPS, Bouttier et al., 2012; C-LAEF, Wastl et al., 2021; OMSZ AROME-EPS, Szintai et al., 2015; AROME-MetCoOp, Müller et al., 2017) are applied to improve forecast skills for high impact weather.

The presented study comprises description of used ALARO model versions in Section 2 and gives an overview of the experiments in Section 3. The case study description and results of respective experiments are shown in Section 4, whereas discussion and layout of further development in mesoscale forecasting follow in Section 5 .

\section{Methodology and description of used LAM NWP systems}

\subsection{LAM NWP systems used in the study}

Four different versions of the ALARO NWP system have been used for experiments and diagnostics described in this paper. The basic setup of the systems is summarized in Table 1 . 
Table 1. Setup of four referenced ALARO versions.

\begin{tabular}{|c|c|c|c|c|}
\hline label & ALADIN/SHMU & A-LAEF & ALADIN/CHMI & ALARO 2 \\
\hline status & operational & $\begin{array}{l}\text { operational } \\
\text { (common RC } \\
\text { LACE) }\end{array}$ & $\begin{array}{l}\text { operational } \\
\text { (at CHMI) }\end{array}$ & $\begin{array}{l}\text { run in testmode at } \\
\text { SHMÚ }\end{array}$ \\
\hline $\begin{array}{l}\text { horizontal } \\
\text { resolution }\end{array}$ & $4.5 \mathrm{~km}$ & $4.8 \mathrm{~km}$ & $2.3 \mathrm{~km}$ & $2.0 \mathrm{~km}$ \\
\hline number of points & $625 \times 576$ & $1250 \times 750$ & $1080 \times 864$ & $512 \times 384$ \\
\hline domain size & $2813 \times 2592 \mathrm{~km}$ & $6000 \times 3600 \mathrm{~km}$ & $2511 \times 2009 \mathrm{~km}$ & $1024 \times 768 \mathrm{~km}$ \\
\hline $\begin{array}{l}\text { number of } \\
\text { vertical levels }\end{array}$ & 63 & 60 & 87 & 87 \\
\hline coupling model & $\begin{array}{l}\text { ARPEGE, } 3 \mathrm{~h} \\
\text { coupling } \\
\text { frequency }\end{array}$ & $\begin{array}{l}16+1 \text { members of } \\
\text { ECMWF EPS, } 6 \mathrm{~h} \\
\text { coupling frequency }\end{array}$ & $\begin{array}{l}\text { ARPEGE, } 3 \mathrm{~h} \\
\text { coupling } \\
\text { frequency }\end{array}$ & $\begin{array}{l}\text { ARPEGE, } 1 \mathrm{~h} \\
\text { coupling } \\
\text { frequency }\end{array}$ \\
\hline forecast ranges & 78/72/72/60 h & $72 /-/ 72 /-\mathrm{h}$ & $72 / 72 / 72 / 54 \mathrm{~h}$ & 78/72/72/60 h \\
\hline Initial times & 00/06/12/18 UTC & 00/12 UTC & 00/06/12/18 UTC & 00/06/12/18 UTC \\
\hline $\begin{array}{l}\text { upper air data } \\
\text { assimilation }\end{array}$ & $\begin{array}{l}\text { spectral blending } \\
\text { by DF }\end{array}$ & $\begin{array}{l}\text { spectral blending } \\
\text { by DF for } 16+1 \\
\text { members }\end{array}$ & BLENDVAR & $\begin{array}{l}\text { none (dynamical } \\
\text { downscaling) }\end{array}$ \\
\hline $\begin{array}{l}\text { surface data } \\
\text { assimilation }\end{array}$ & $\begin{array}{l}\text { CANARI optimal } \\
\text { interpolation }\end{array}$ & $\begin{array}{l}\text { Ensemble data } \\
\text { assimilation based } \\
\text { on CANARI OI }\end{array}$ & $\begin{array}{l}\text { CANARI optimal } \\
\text { interpolation }\end{array}$ & $\begin{array}{l}\text { none (LBC } \\
\text { downscaling) }\end{array}$ \\
\hline initialization & none & none & $\begin{array}{l}\text { Incremental digital } \\
\text { filter in short cut- } \\
\text { off production } \\
\text { analysis }\end{array}$ & digital filter \\
\hline model physics & ALARO-1vB & $\begin{array}{l}\text { ALARO-1 multi- } \\
\text { physics + surface } \\
\text { stochastic physics } \\
(\mathrm{SPPT})\end{array}$ & $\begin{array}{l}\text { ALARO-1vB, } \\
\text { adapted for } \\
\text { convection- } \\
\text { permitting scales }\end{array}$ & $\begin{array}{l}\text { The same as } \\
\text { ALADIN/CHMI }\end{array}$ \\
\hline model dynamics & $\begin{array}{l}\text { Hydrostatic } \\
\text { formulation, } \\
\text { spectral, semi- } \\
\text { implicit, } 2 \text { time } \\
\text { level semi- } \\
\text { lagrangian } \\
\text { scheme }\end{array}$ & $\begin{array}{l}\text { The same as } \\
\text { ALADIN/SHMU }\end{array}$ & $\begin{array}{l}\text { Non-hydrostatic } \\
\text { formulation, } \\
\text { spectral, semi- } \\
\text { implicit } 2 \text { time } \\
\text { level iterative } \\
\text { centered implicit } \\
\text { scheme }\end{array}$ & $\begin{array}{l}\text { The same as } \\
\text { ALADIN/CHMI }\end{array}$ \\
\hline
\end{tabular}




\subsubsection{ALADIN/SHMU model description}

The main operational model used at SHMÚ is the ALARO configuration of the ALADIN NWP system (Termonia et al., 2018) with $4.5 \mathrm{~km}$ horizontal resolution and 63 vertical levels. This version is hydrostatic with spectral, semi-implicit (Simmons and Burridge, 1981), 2-time-level semi-lagrangian scheme (Hortal, 2002).

The ALARO-1vB upper air physics setting (Brožková et al., 2019) and ISBA surface scheme (Noilhan and Planton, 1989) with CY43t2_bf11 code version are largely applied. The parameterization of turbulence (sometimes modified in ALARO experiments described later) includes the emulated TKE-based scheme (Ďurán et al., 2014; 2018) denoted as model II (MD2) and the Geleyn-Cedilnik formulation of the mixing length (Cedilnik et al., 2005; Geleyn et al., 2006). The global model ARPEGE provides lateral boundary condition (LBC) data 4 times/day with 3-hourly frequency. For initial conditions the operational ALADIN/SHMU system uses spectral blending by digital filter algorithm for upper air atmospheric fields (Derková and Belluš, 2007). For surface data assimilation, the optimal interpolation scheme denoted CANARI (Giard and Bazile, 2000) is applied. See Derková et al. (2017) for more details on the current operational version of ALADIN/SHMU.

\subsubsection{A-LAEF system description}

The former utilization of ensembles at SHMÚ has been restricted mostly to the global systems (ECMWF ENS, GEFS), which were used mainly for the mediumrange forecasts. Recently, a new short-range ensemble weather forecasting system A-LAEF (ALARO Limited Area Ensemble Forecasting), available to our forecasters since July 2020 (Belluš, 2020a; Belluš et al., 2019), can offer, among the other enhancements, a 4-times higher spatial resolution than its predecessor. Technically, it is a sequel to the former ALADIN-LAEF system developed within the RC LACE cooperation (Regional Cooperation for numerical weather modeling on Limited Area in Central Europe, Wang et al., 2017a). The ALADINLAEF system had been operational at ECMWF since 2011 (Wang et al., 2011) until recently, when it was replaced by the A-LAEF system. Moreover, the new A-LAEF system has increased horizontal and vertical resolution $(4.8 \mathrm{~km} / 60 \mathrm{~L})$, and involves new perturbation techniques. The key components of the A-LAEF ensemble system are the followings:

○ Multi-physics based on ALARO-1 parameterizations, which can seamlessly operate on the horizontal scales from 2 to $10 \mathrm{~km}$ (Termonia et al., 2018) and is capable of simulating the uncertainty on meso-synoptic scales. There are 4 different groups of settings for turbulence, microphysics, deep and shallow convection, and radiation parameterizations, hereafter referred to as MP clusters (Belluš, 2019); 
○ Ensemble of surface data assimilations ESDA (Belluš et al., 2016) with the upper-air spectral blending by digital filter initialization (Derková and Belluš, 2007);

○ The stochastic perturbation of physics tendencies for the surface prognostic fields (Wang et al., 2019).

Concerning turbulence, the emulated QNSE parameterization of turbulent fluxes (Sukoriansky et al., 2005) and the Geleyn-Cedilnik mixing length limited in stable regimes (Ďurán, 2014) are applied in MP clusters 2 and 3, whereas members of the clusters 1 and 4 run with the same turbulence scheme as ALADIN/SHMU. The integration domain of A-LAEF system covers large area including Europe, the whole Mediterranean Sea, and the part of Western Asia (Fig. 1). The ensemble comprises 16 perturbed members and 1 control run coupled to the ECMWF ENS, and the probabilistic products are available twice a day (based on the 00 and 12 UTC runs) for the next 3 days.

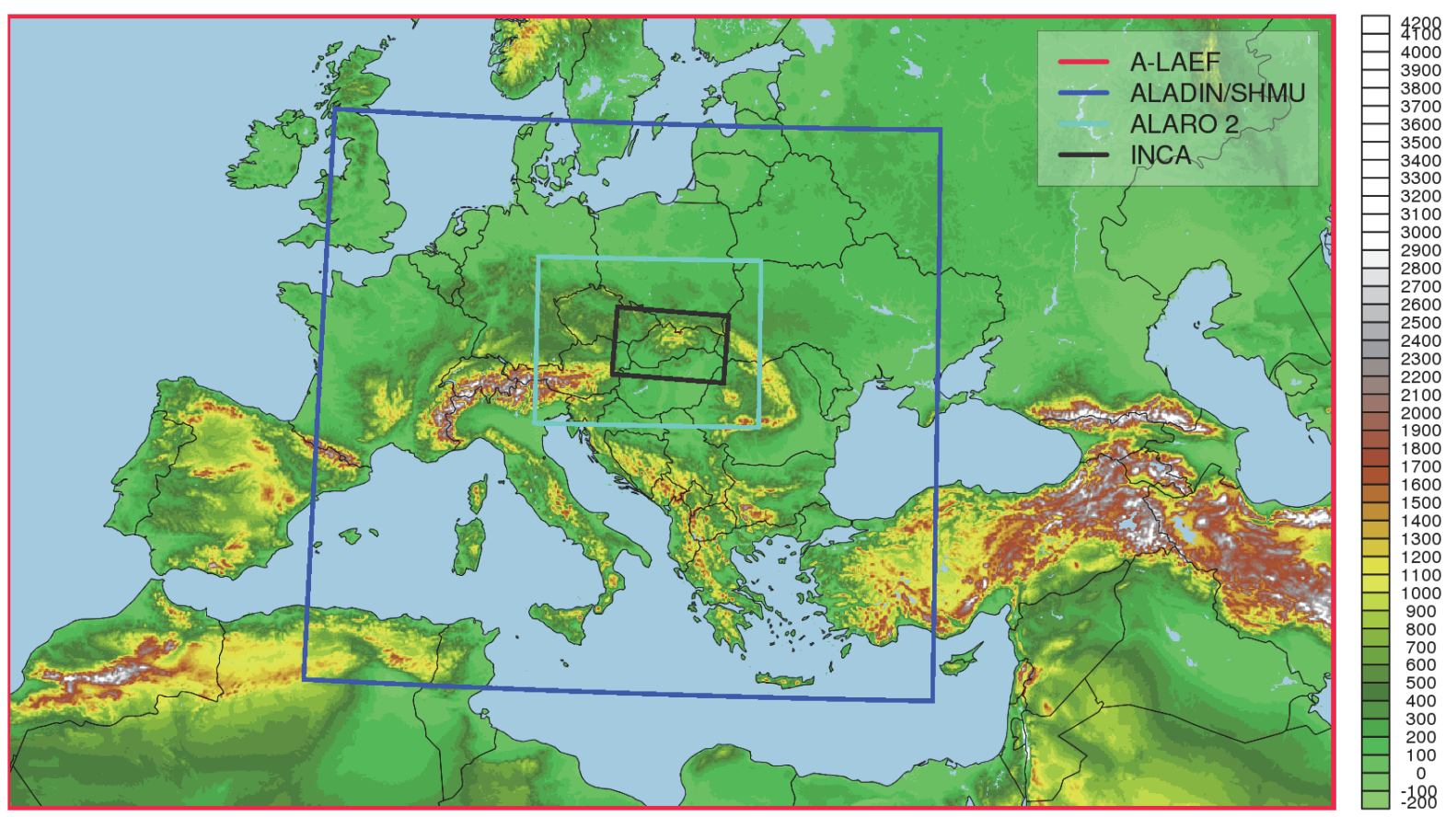

Fig. 1. Domains of the model configurations used in this study: A-LAEF (with model topography), and domain borders of ALADIN/SHMU, ALADIN/CHMI, ALARO $2 \mathrm{~km}$, and of the INCA nowcasting system. 


\subsubsection{ALADIN/CHMI model description}

The ALARO configuration run at CHMI (Brožková et al., 2019, 2021) at $2.3 \mathrm{~km}$ horizontal resolution uses non-hydrostatic dynamics, spectral, semi-implicit 2time-level iterative centered implicit scheme (Bénard et al., 2010). The BLENDVAR method (Bućánek et al., 2015) is applied for the analysis of the initial atmospheric fields. Incremental digital filter (Fischer and Auger, 2011) is applied for short cut-off production analysis.

The physical parameterization of this version is similar to ALADIN/SHMU but adapted for higher resolution (because deep convection and its effects are partially resolved, which is treated within the $3 \mathrm{MT}$ scheme). This ALARO version was used only for experiments with radar data assimilation (see Section 3), which is not available in ALADIN/SHMU yet.

\subsubsection{ALARO 2 setup description}

An ALARO version similar to ALADIN/CHMI is used at SHMÚ at horizontal resolution $2 \mathrm{~km}$ in dynamical adaptation mode without assimilation cycling and on a smaller domain (due to computational costs). The model uses digital filter initialization (Lynch et al., 1997). The role of the digital filter is to filter out the noise introduced by the interpolation of LBCs into target resolution and to ensure higher numerical stability at the beginning of the run. Although running daily, the model is not considered to be fully operational, and its purpose is in testing and tuning of the physical parameterization and gaining experience with the convection-permitting mode (important for the future upgrade of the current ALADIN/SHMU to higher resolution). Several experiments in this study were based on the ALARO 2 experimental setup with certain modifications (described later).

\subsection{Postprocessing and diagnostic methods}

\subsubsection{Parameters of convective environment}

Processing of the ALADIN/SHMU outputs involved calculation of convective parameters and indices averaged for longer ( $3 \mathrm{~h})$ timescales, including surfacebased convective available potential energy (SBCAPE), low-level divergence (average of the 980, 950,925, 900,875, $850 \mathrm{hPa}$ divergence), relative humidity (average of the 2, 300, 500, 750, 1000, 1500, 2000, $3000 \mathrm{~m}$ AGL humidity) and $0-6 \mathrm{~km}$ wind shear. Averaging was used to characterize the prevailing conditions and environment of deep convection focusing on instability, humidity and saturation of the air, lift, shear during periods for which accumulated precipitation was calculated. These parameters were based on the forecasts of the operational ALADIN/SHMU model. 


\subsubsection{Cloud top height and temperature assessment}

Cloud top height and cloud top temperature (CTT) were estimated from ALARO 2 outputs (simulated brightness temperature is not available as a diagnostic parameter yet). Cloud tops were identified upon thresholds of cloud ice (CLI) or cloud liquid water (CLW) mixing ratios forecast by the models. Further, extinction coefficients for ice were assessed from CLI (Stoelinga and Warner, 1999). It is often considered that CLW exceeds $0.01 \mathrm{gm}^{-3}$ in water clouds (Kokhanovsky, 2004), and the extinction coefficient for ice in thick cirrus clouds is about $1.0 \mathrm{~km}^{-1}$ (Platt, 1997). However, in the presented case, the identification thresholds had to be higher $\left(0.02 \mathrm{gm}^{-3}\right.$ for CLW and $2.5 \mathrm{~km}^{-1}$ for the CLI extinction coefficient) to better distinguish the top of a precipitating convective cloud from a cirrus cloud aloft. The algorithm also evaluated the depth of the cloudiness inferred from CLW and CLI profiles and the maxima of these parameters.

\subsection{Observation data used for experiments evaluation}

For evaluation of precipitation forecasts, analyses of the INCA nowcasting system (Méri et al., 2018, 2021) were used, which process inputs from both AWS and radar observations. At SHMÚ, hourly analyses of precipitation are generated on a $1 \times 1 \mathrm{~km}$ resolution domain. Radar reflectivity data were from the composite of Slovak, Hungarian, and Czech radars operated by SHMÚ, OMSZ, and ČHMÚ national meteorological services (Jurašek et al., 2017; Sipos et al., 2021; Novák et al., 2019). These images have $660 \mathrm{~m}$ horizontal resolution and leaflet.js API was used for the visualisation with Wikimedia maps in the background (Leaflet, 2021; Wikimedia, 2021). Column maximum radar reflectivity data (Cmax) were retrieved with projections of the vertical profiles of the maximum reflectivity to four sides of the image (from the central axis toward the respective side). The constant altitude plan position indicator (CAPPI) horizontal cross-sections at 2 and $3 \mathrm{~km}$ height were generated for determination of the type and structure of convective cells. Doppler radar velocity measurements were analyzed from plan position indicator (PPI) data at $0.5,1.0,1.5$, and 2.0 degree of antenna elevations measured by respective SHMÚ radars with $250 \mathrm{~m}$ gatewidth. The Nyquist velocity interval for these PPI data was $\pm 40 \mathrm{~m} / \mathrm{s}$. Cloud top brightness temperature (CTB) data were inferred from 5 minute Rapid Scanning Service (RSS) satellite data from the METEOSAT 10 EUMETSAT IR $10.8 \mu \mathrm{m}$ imagery with use of the MSGProc/ViewMSG programs (Kaňák, 2006). The horizontal resolution of the original data was nearly $3 \times 3 \mathrm{~km}$ in the area of Slovakia. For better geolocation of the coldest cloud areas, the data were transformed to higher resolution with 0.0040 degrees per pixel in longitudinal and 0.0027 degrees per pixel in latitudinal direction with linear interpolation. 


\section{Description of experiments}

Model experiments in the June 7,2020 case were run with various types of input data or setups in data assimilation, dynamics, or physical parameterization (Table 2), which were sometimes different compared to the operational one. Data assimilation has been developed and tested mainly in the frame of the hydrostatic ALADIN/SHMU model (with radar data assimilation as exception). Predictability of the convective events in this case was studied with the operational version of the A-LAEF system. Here, the main focus was on the accuracy of the $3 \mathrm{~h}$ precipitation forecast, concerning both intensity and spatial distribution of precipitation. Experiments related to model dynamics and diagnostics applied the convection-permitting configuration, close to ALARO 2. These runs were used to explore the numerical stability and effectiveness/performance of such configuration, and concentrated on non-hydrostatic features and life-cycle of individual cells.

Table 2. Labelling and description of experiments.

\begin{tabular}{|c|c|c|}
\hline $\begin{array}{l}\text { Experiment } \\
\text { label }\end{array}$ & $\begin{array}{l}\text { Basic model } \\
\text { version/domain }\end{array}$ & Description \\
\hline P432 & ALADIN/SHMU & $\begin{array}{l}\text { Reference version for BLENDVAR experiments. No upper-air } \\
\text { data assimilation, only blending by DF. }\end{array}$ \\
\hline ZTDS & ALADIN/SHMU & $\begin{array}{l}\text { BLENDVAR experiment with HRWIND AMV and GNSS } \\
\text { ZTD with static whitelist in 3D-Var. }\end{array}$ \\
\hline AWS1 & ALADIN/SHMU & $\begin{array}{l}\text { BLENDVAR experiment with HRWIND AMV and local } \\
\text { AWS from OPLACE in 3D-Var. }\end{array}$ \\
\hline ALLD & ALADIN/SHMU & $\begin{array}{l}\text { BLENDVAR experiment with all available high-resolution data: } \\
\text { HRWIND AMV, GNSS ZTD, local AWS, EMADDC and } \\
\text { OPLACE Mode-S, high resolution BUFR TEMP in 3D-Var. }\end{array}$ \\
\hline C-REF & ALADIN/CHMI & ALADIN/CHMI reference. \\
\hline C-RAD & ALADIN/CHMI & ALADIN/CHMI, with OPERA radial winds. \\
\hline ID00 & ALARO 2 & $\begin{array}{l}\text { Reference ICI scheme without NHHY parameter, } 73 \text { model } \\
\text { levels. }\end{array}$ \\
\hline ID01 & ALARO 2 & SI scheme with NHHY=1.2. \\
\hline IH00 & ALARO 2 & As ID00 but with $1 \mathrm{~km}$ resolution and 100 levels. \\
\hline IH01 & ALARO 2 & As ID01 but with $1 \mathrm{~km}$ resolution and 100 levels. \\
\hline SWDIAG & ALARO 2 & $\begin{array}{l}73 \text { model levels, ZTDS data for surface analysis, QNSE } \\
\text { parameterization of turbulent fluxes, limitation for the Geleyn- } \\
\text { Cedilnik mixing length. }\end{array}$ \\
\hline
\end{tabular}




\subsection{Data assimilation experiments}

As mentioned in Section 2.1, for initial conditions of the upper-air atmospheric fields, the operational ALADIN/SHMU system uses spectral blending by digital filter (DF) technique - without a direct use of observations. An extension of this operational setup is proposed by an introduction of the three-dimensional variational data analysis (3D-Var) step. 3D-Var is operationally used in similar ALADIN systems and many other LAM NWP models worldwide (Gustafsson et al., 2018). Our goal is to use a combination of DF blending step and 3D-Var (BLENDVAR) configuration (Bučánek et al., 2015). Such a combination enables us to benefit from large scale analysis provided by 4D-Var data assimilation of the global model Arpege via DF blending, and to improve the small scales description by using high resolution observations within ALADIN 3D-Var.

In the basic BLENDVAR prototype at SHMÚ, the conventional observations (AMDAR, SYNOP, TEMP) and AMV HRWIND are utilized in the upper-air 3DVar. The observation data are taken from OPLACE - a common operational database of RC LACE (Trojáková et al., 2019). Downscaled ensemble background error covariance matrix is applied (Bučánek and Brožková, 2017). No change in surface assimilation with respect to operational setup is made. Also, the operational 6-hourly assimilation cycling interval was kept. This BLENDVAR configuration is not yet superior to the operational versions in terms of the objective verification scores (not shown). Therefore, new sources of high resolution observations are being tested aiming to improve the small-scale features. These comprise:

○ An extended set of about 500 national automatic weather stations (AWS) reports from OPLACE, that is not available in GTS;

○ Zenith total delays (ZTD) data from almost 60 GNSS stations processed at the Slovak University of Technology (Imrišek et al., 2020);

o The Mode-S aircraft measurements available from OPLACE, used with a thinning distance of $25 \mathrm{~km}$, and $1500 \mathrm{~Pa}$ : EHS data from EMADDC and MRAR data from the Czech Republic and Slovenia;

o High resolution radiosonde data in BUFR format, that enables to take into account real positions of measurements both in space and time. Total increase of the assimilated data amount is quadrupled;

o Radial wind velocity data from the OPERA OIFS project, used with a thinning distance $8 \mathrm{~km}$ (Čatlošová, 2020).

A typical increase of data amount of individual datasets listed above compared to basic 3D-Var setup is shown in Table 3. 
Table 3. Number of observation reports and number of individual data typically assimilated in a reference 3D-Var setup (left) and in the experiments with enhanced data sets (right) for the 12 UTC network

\begin{tabular}{lcccc}
\hline \hline & \multicolumn{2}{c}{ reference 3D-Var setup } & \multicolumn{2}{c}{ enhanced observations usage } \\
\cline { 2 - 5 } observations & No of reports & No of data & No of reports & No of data \\
\hline \hline SYNOP/AWS & $\sim 1500$ & $\sim 5000$ & $\sim 2000-2200$ & $\sim 6000$ \\
GNSS ZTD & - & - & $\sim 55$ & $\sim 55$ \\
AMDAR/Mode-S & $\sim 350$ & $\sim 1000$ & $\sim 4500$ & $\sim 13000$ \\
HRWIND AMV & $\sim 50-100$ & $\sim 100-200$ & $\sim 50-100$ & $\sim 100-200$ \\
TEMP radiosonde & $\sim 60$ & $\sim 14000$ & $\sim 60$ & $\sim 70000$ \\
$\begin{array}{l}\text { Radial wind } \\
\text { velocities }\end{array}$ & - & - & $\sim 33000$ & $\sim 370000$ \\
\hline
\end{tabular}

The series of BLENDVAR experiments were run for the case study of June 7, 2020 and the impact on the precipitation forecast was evaluated. In each experiment a different high resolution observation set was utilized, as summarized in Table 2. The experiment setup consisted of 3 days of assimilation cycling starting from June 4, 2020, 00 UTC. Then the production forecast was launched for 00 and 12 UTC.

\subsection{Convection permitting experiments: non-hydrostatic dynamics}

For realistic simulation of phenomenon at kilometric and hectometric resolutions, the non-hydrostatic equation system must be exploited. The iterative centered implicit (ICI) integration scheme (Bénard, 2003) is implemented in the current dynamical core, because the original semi-implicit (SI) scheme with stable extrapolation SETTLS (Hortal, 2002) used for the hydrostatic system was found unstable.

In order to achieve stability of the ICI scheme already after the first iteration, the linear operator associated with the semi-implicit scheme must include two reference temperature profiles (Bénard, 2003, 2004). Because the real atmosphere can not have two profiles at the same time, the linear operator can not be obtained by linearization of the nonlinear system around the reference state.

This leads to the idea that there exists a class of linear operators that would stabilize the SI time stepping with SETTLS extrapolation for a non-hydrostatic model as well. To investigate the idea, a class of new operators was defined, where 
each equation is written as the sum of hydrostatic linear operator terms plus nonhydrostatic departure terms. The departure terms in each equation are weighted by the unique constant parameter. When all parameters are set to 1, the nonhydrostatic linear operator is obtained. If the parameters are set to 0 , the linear operator yields to the hydrostatic one. Therefore, the approach is called NHHY, when the linear operator is modified using an additional set of parameters. The feasibility of elimination into a single variable Helmholz solver for horizontal divergence provides constraints between parameters, and the final spectral solver contains only two additional tunable parameters concerning the existing state. The paper with detailed description is currently in preparation.

A set of experiments was performed to validate the stability of NHHY approach summarized in Table 4. Two model configurations were tested, derived from the experimental ALARO 2 setup. First configuration was run at the resolution of $2 \mathrm{~km}, 73$ levels, and time step $120 \mathrm{~s}$ (experiments ID00 and ID01), and the second one with resolution $1 \mathrm{~km}, 100$ levels, and time step $60 \mathrm{~s}$ (IH00 and IH01 experiments). The stability and efficiency of SI SETTLS scheme with NHHY parameters equal to 1.2 was compared against reference results obtained with the ICI scheme. The results are discussed in the Section 4.5.1.

Table 4. Performance of various experiments with ALARO model dynamics with $2 \mathrm{~km}$ and $1 \mathrm{~km}$ horizontal resolution, see Table 1 and Table 2 for the basic setup

\begin{tabular}{lcccc}
\hline \hline Experiment & ID00 & ID01 & IH00 & IH01 \\
\hline \hline Integration time of 15 h forecast [s] & 129 & 92 & 877 & 701 \\
\hline
\end{tabular}

\subsection{Convection-permitting experiments: structure and evolution of convective cells}

The SWDIAG experiment applied the emulated QNSE parameterization of turbulent fluxes and the Geleyn-Cedilnik mixing length limited in stable regimes as in the A-LAEF 2nd MP cluster (see Section 2). The analysis of the ZTDS assimilation experiment (Table 2) was used as well. This combination provided better agreement with precipitation observation as the reference ALARO 2 setup (mainly in temporal and spatial distribution of intense convection), which was important for the diagnostics of severe weather (Section 4.5) and comparison of forecast and observed cloud properties. 


\section{Case study and results}

\subsection{General description}

The region of Slovakia was situated in a moist, warm, and buoyant air mass ahead of a cold front, which was slowly propagating eastward (and reached the borders of the Czech Republic and Slovakia on June 7, 2020, at around 20 UTC). Deep convective clouds started to form after 08 UTC and propagated northward. Thunderstorms typically occurred along prefrontal convergence lines (Fig. 2a). The radar images and animations indicated lines of multicells and multicellular development. Mesocyclonic storms were not documented in Slovakia, although a tornado was reported from Kaniów, southern Poland, at around 12 UTC (ESWD, 2020). In the afternoon hours (12-14 UTC), the most intense thunderstorms were developing in the proximity of a very long convergence line over western Hungary and Slovakia, continuing to southern Poland (denoted line L1). These thunderstorms caused heavy rain and hail. There were numerous reports above all from Hungary, e.g., from the surrounding of Esztergom and Dorog at the border to Slovakia (Dorog-Esztergom Időjárása, 2020). Overall $30.8 \mathrm{~mm}$ of precipitation was reported from the close meteorological station at Tát (OMSZ, 2020). It is probable that these events can be attributed to the cell denoted C1. Later, convection dissipated along the L1 line, but another one (L2) formed over southwestern Slovakia at around 18 UTC causing local flash floods (Fig. 2b). A related car accident was noted near Tesárske Mlyňany probably in relation with a heavy thunderstorm denoted C2. Large hail was reported from Michalovce in the eastern part of Slovakia at around 20 UTC (cell C3). The numerical simulations of the event mostly concentrated on the above mentioned dominant features. 

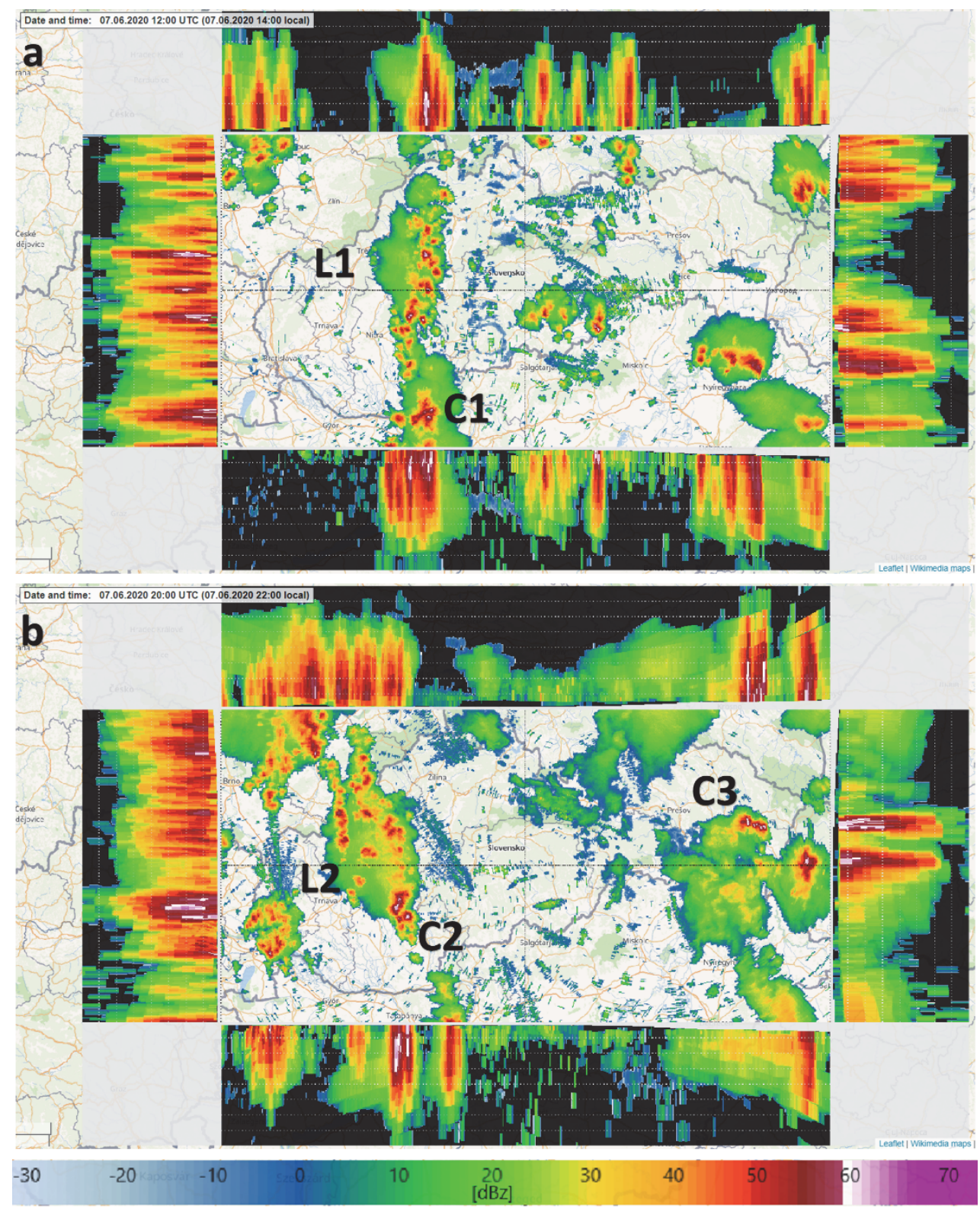

Fig. 2. Column maximum (Cmax dBz) radar reflectivity of the SHMÚ, ČHMÚ, and OMSZ composite imagery with side views (vertical profiles with $2 \mathrm{~km}$ mesh): a) valid for June 7, 2020, 12:00 UTC (L1 and C1 denote convergence line and cell investigated in the study); b) valid for June 7, 2020, 20:00 UTC (L2, C2, and C3 refer to significant convective features studied during this period).

\subsection{Convective environment}

The forecasts of the deterministic ALADIN/SHMU 00 UTC model run for the 12-15 UTC period of June 7 (Fig. 3, top left) showed high surface-based CAPE (mostly exceeding $1000 \mathrm{~J} / \mathrm{kg}$ ) over Slovakia, which also corresponded with TEMP rawinsonde reports (SBCAPE of $1523.6 \mathrm{~J} / \mathrm{kg}$ assessed from Budapest and $810.26 \mathrm{~J} / \mathrm{kg}$ from Gánovce soundings at $12 \mathrm{UTC}$ ). Moist areas could be seen on the averaged $0-3 \mathrm{~km}$ relative humidity image for the central part of Slovakia, 
whereas the air over southwestern Slovakia was less saturated (Fig. 3, top right). The peak $0-500 \mathrm{~m}$ specific humidity (exceeding $12 \mathrm{~g} / \mathrm{kg}$ ) and total precipitable water (around $34 \mathrm{~mm}$ ) was situated over the southern part of central Slovakia, east of L1 (not shown), which coincided with CAPE maxima, and the model development of the deep convection was also largely preferred in this region. It could be deduced that divergence of flow was rather prevailing in the southwestern flank of Slovakia and over its eastern part, while low-level convergence areas appeared more frequent over the central part of Slovakia although its distribution was highly influenced by the rugged orography in this region (Fig. 3, bottom left). There was only little wind shear between the $10 \mathrm{~m}$ and $6 \mathrm{~km}$ heights over the western part of Slovakia (Fig. 3, bottom right), which probably explains the lack of organized convective systems in this region and the typically multicellular behavior of the convection.

In the evening hours (18-21 UTC), the air was still conditionally unstable with maximum SBCAPE just over the southern part of L2 (exceeding $1400 \mathrm{~J} / \mathrm{kg}$ - not shown). The wind shear also slightly increased over this area - probably as a consequence of the approaching cold front.
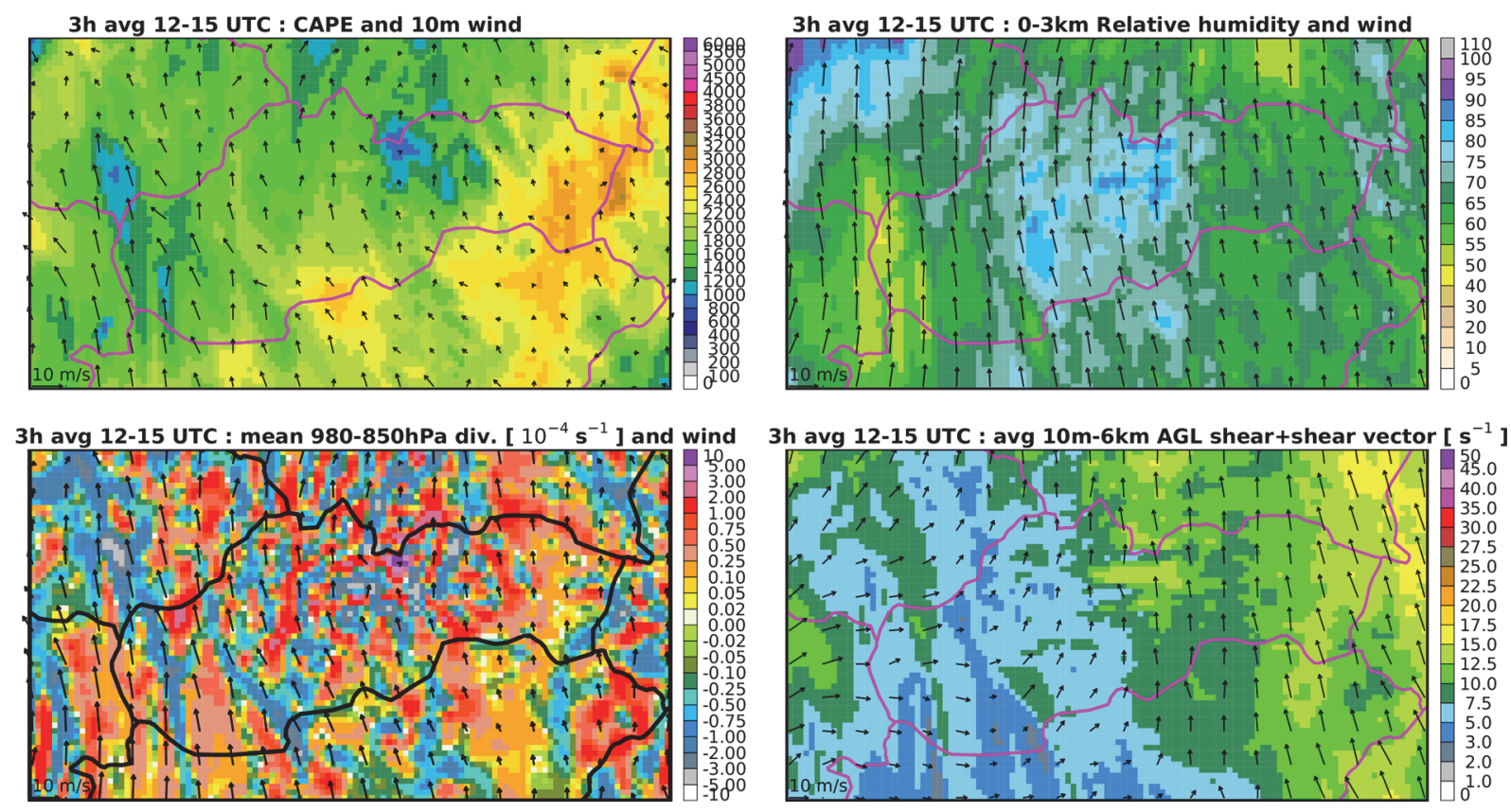

Fig. 3. Forecasts of the ALADIN/SHMU convective environment parameters based on June 7, 2020, 00:00 UTC and time-averaged for the 12-15 UTC period of the same day. Upper left: SBCAPE $[\mathrm{J} / \mathrm{kg}$ ] and $10 \mathrm{~m}$ wind $[\mathrm{m} / \mathrm{s}]$, upper right: $0-3 \mathrm{~km}$ relative humidity $[\%]$ and wind $[\mathrm{m} / \mathrm{s}]$, lower left: $980-850 \mathrm{hPa}$ divergence $\left[10^{-4} \mathrm{~s}^{-1}\right]$ and wind $[\mathrm{m} / \mathrm{s}]$, lower right: $10 \mathrm{~m}-6 \mathrm{~km}$ AGL wind shear $\left[\mathrm{s}^{-1}\right]$ (absolute value in shades). 


\subsection{Operational models and data assimilation experiments}

\subsubsection{The 12-15 UTC period (along the line L1)}

The most intense precipitation in this period occurred in the western part of Slovakia with a maxima exceeding $30 \mathrm{~mm} / 3 \mathrm{~h}$ (Fig. 4, top left). The spatial coverage and intensity of the forecast precipitation was underestimated in the 00 UTC run of the operational SHMÚ model (Fig. 4, top right). In the operational A-LAEF output, the position of the intense precipitation fitted better the observed distribution in the western part of Slovakia in average (Fig. 4, bottom left) and coincided with the position of the L1 line. There was less certainty regarding the position and intensity of the extremes, but the EPS maxima predicted $20-30 \mathrm{~mm}$ peaks along the main convergence line (Fig. 4, bottom right). Operational deterministic forecast was improved using 3D-Var data assimilation of high resolution observations. Any of BLENDVAR experiments yield more realistic precipitation forecast against the reference P432 shown in Fig. 5, upper right plot - both the position of precipitation patterns and their intensities were captured better. The most promising experiment utilized humidity information from ZTD GNSS data (Fig. 5, middle left plot), although the most intense precipitation was situated at least $50-70 \mathrm{~km}$ south of the observed one. There were also more precipitation patterns over Hungary and northwestern Slovakia. Even stronger convective activity near the cell $\mathrm{C} 1$ of Fig. $2 a$ was indicated in the AWS1 experiment with an enhanced number of assimilated automatic weather stations (Fig. 5, middle right plot). These results suggest, that this convective case was rather sensitive to initial conditions, where any change led to a slightly different forecast. The impact of utilization of radial wind velocity measurements from meteorological radars was checked independently, as those experiments were conducted using ALADIN/CHMI configuration within an RC LACE scientific stay. In this case the reference forecast (C-REF, Fig. 5, bottom left plot) was already much better than the ALADIN/SHMU one, also due to the higher resolution of ALADIN/CHMI $(2.3 \mathrm{~km} / \mathrm{L} 87)$ and its non-hydrostatic dynamics. With assimilation of radial winds, the precipitation coverage was changed and more local precipitation patterns appeared - albeit not always correctly. The local maxima near the $\mathrm{C} 1$ cell on the border of Slovakia and Hungary were more realistic (C-RAD, Fig. 5, bottom right plot). 

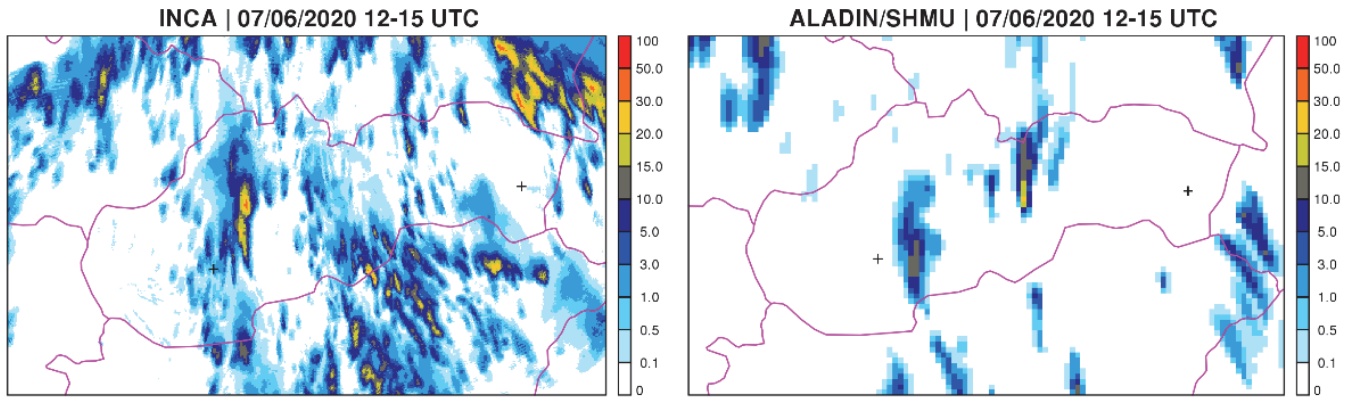

A-LAEF (EPS MEAN) | 07/06/2020 12-15 UTC
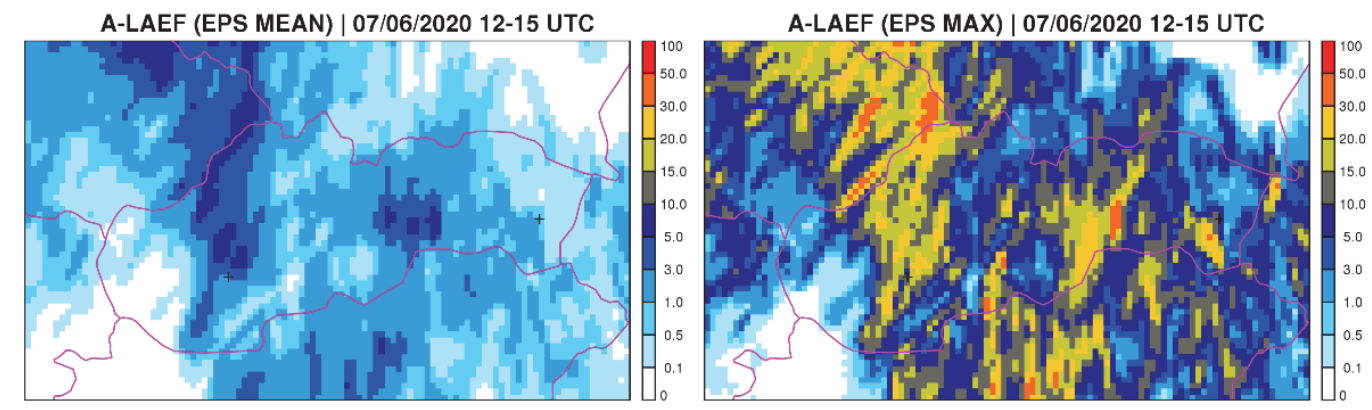

Fig. 4. 3-hourly precipitation accumulation [mm] for June 7, 2020, 12-15 UTC period: from INCA analysis (top left); ALADIN/SHMU operational forecast (top right); A-LAEF ensemble mean (bottom left); A-LAEF maximum of ensemble (bottom right). The model forecasts are based on the 00 UTC run.
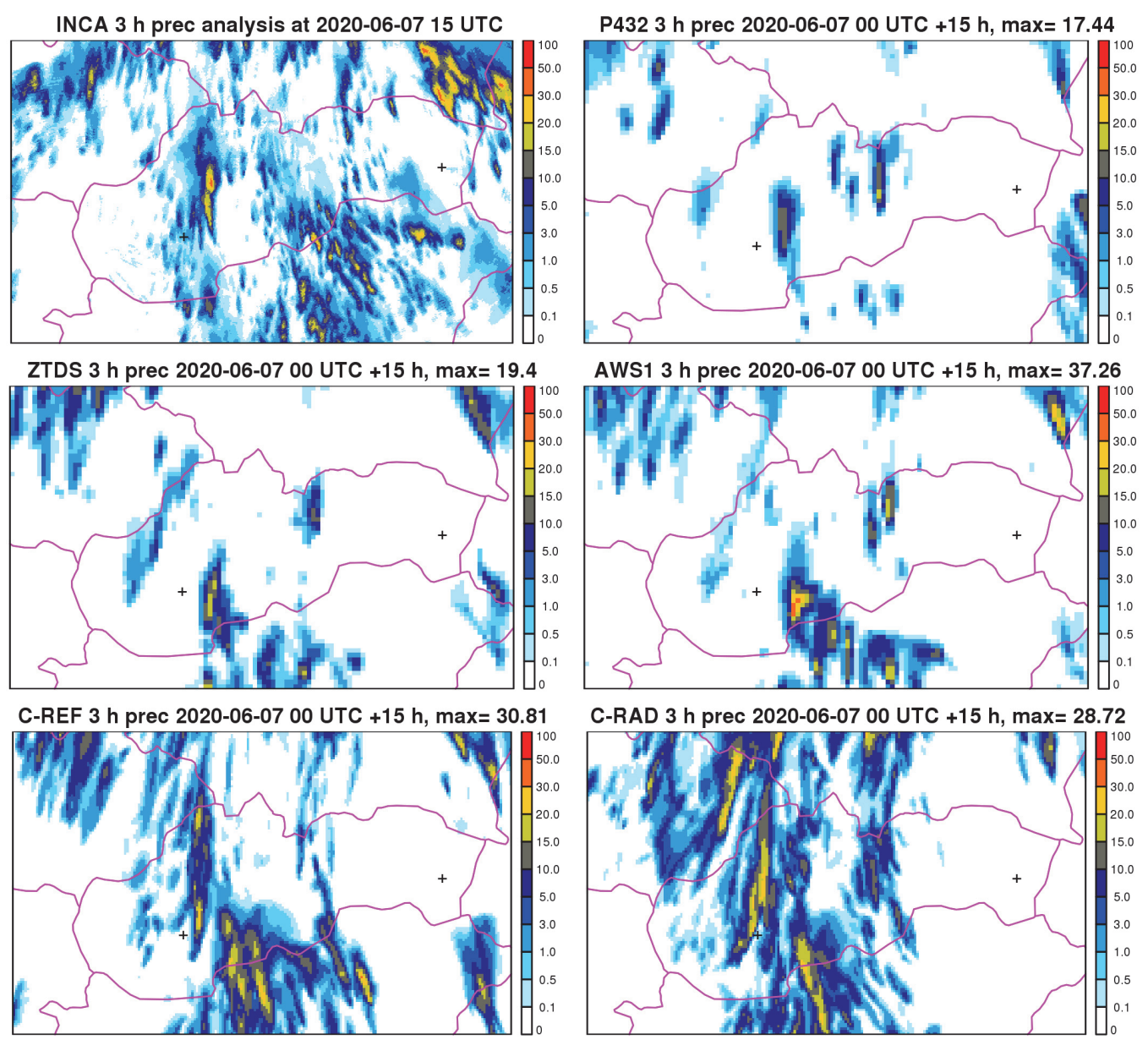

Fig. 5. 3-hourly precipitation accumulation [mm] for June 7, 2020, 12-15 UTC period: INCA analysis (top left); P432 reference experiment (top right); and BLENDVAR data assimilation experiments referred in Table 2: ZTDS (middle left), AWS1 (middle right), C-REF (bottom left), and C-RAD (bottom right). All model forecasts are based on the 00 UTC run. 


\subsubsection{The 18-21 UTC period (line L2, cells C2 and C3)}

In the evening period, the operational SHMÚ forecast (based on both 00 and 12 UTC runs) predicted the cold front-related precipitation but not the heavy rainfall on the convergence line L2 (Fig. 7, second image in the first row). Some additional (but rather weak) patterns could be seen also in southeast Slovakia, in relation with $\mathrm{C} 3$. The BLENDVAR experiment with additional ZTD data (ZTDS, Fig. 6, middle left panel) remarkably improved the localization of precipitation along the convergence line $\mathrm{L} 2$, and indicated the presence of the convective cell C2 (to be compared to INCA analysis, Fig. 6 top left panel, and P432 reference, Fig. 6 top right panel). The false precipitation over Moravia and southwestern Slovakia were reduced. Precipitation forecasts based on the experiment, where 3D-Var comprises a whole enhanced set of data (ALLD, Fig. 6, middle right panel), maintained overall improvement with respect to the P432 reference, but some of the local features became lost. All BLENDVAR experiments failed to predict precipitation over central Slovakia and on the border with Poland. Experiment with radial wind velocity data assimilation succeeded to indicate convective precipitation in western Slovakia, albeit the maximum was shifted too westerly. Development of the convergence line L2 was clearly indicated with respect to the reference forecast. Precipitation patterns in central Slovakia were also present but easterly shifted, and a signal of convective activity in southern Poland and near the Ukrainian border was correct (Fig. 6, bottom right panel). 
INCA $3 \mathrm{~h}$ prec analysis at 2020-06-07 21 UTC

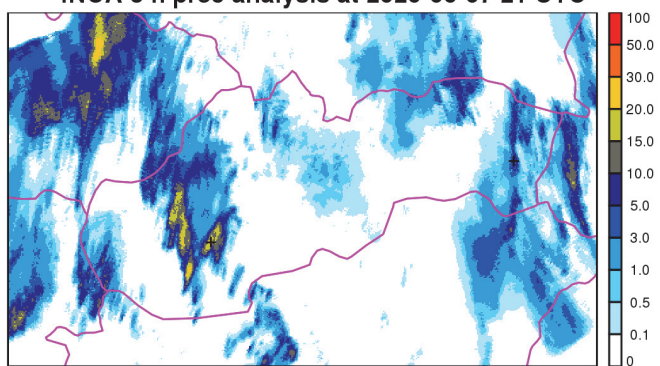

ZTDS 3 h prec 2020-06-07 12 UTC +9 h, $\max =24.45$

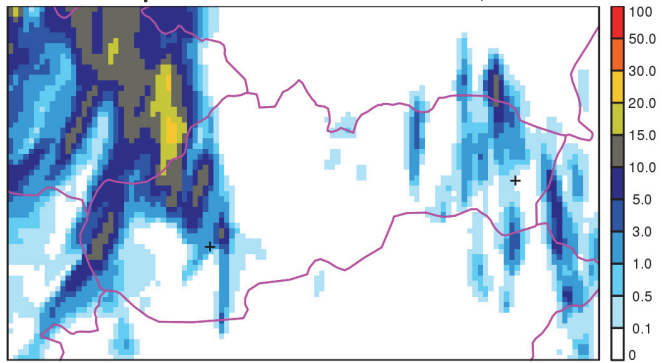

C-REF 3 h prec 2020-06-07 12 UTC +9 h, max $=44.86$

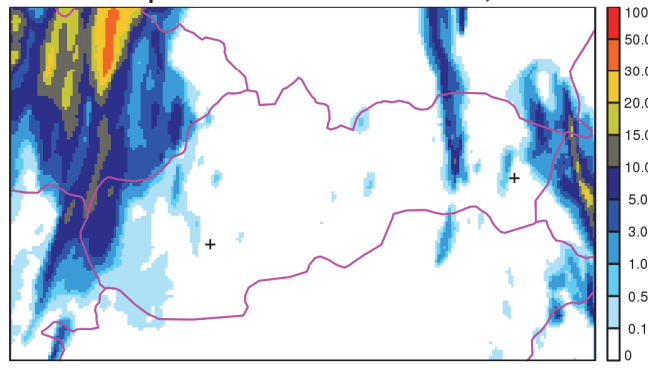

P432 3 h prec 2020-06-07 12 UTC +9 h, $\max =27.66$

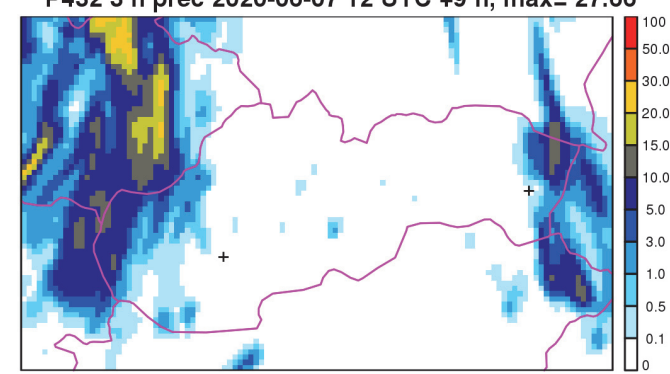

ALLD 3 h prec 2020-06-07 12 UTC +9 h, $\max =20.82$

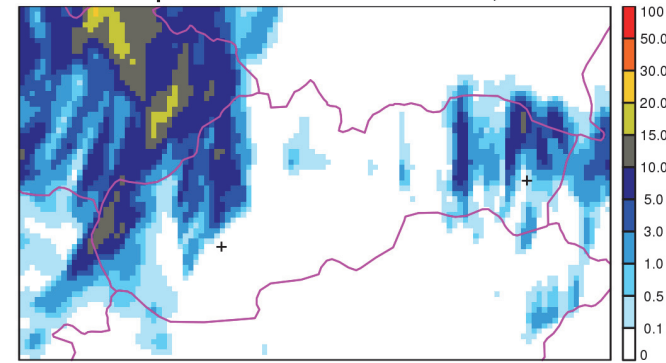

C-RAD 3 h prec 2020-06-07 12 UTC +9 h, max $=49.64$

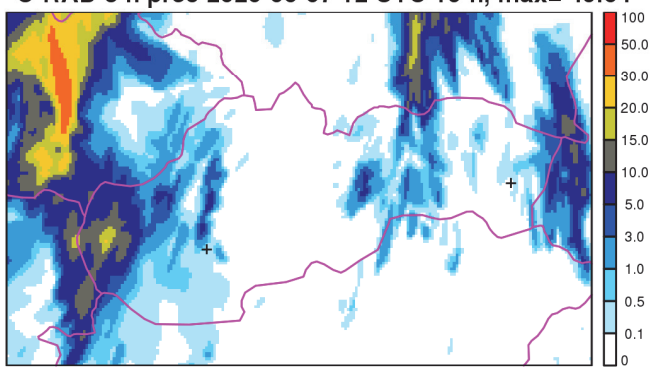

Fig 6. 3-hourly precipitation accumulation [mm] for June 7, 2020, 18-21 UTC period: INCA analysis (top left); P432 reference experiment (top right); and BLENDVAR data assimilation experiments referred in Table 2: ZTDS (middle left), ALLD (middle right), CREF (bottom left), and C-RAD (bottom right). All model forecasts are based on the 12 UTC run. Position of Tesárske Mlyn̆any and Michalovce is marked by black crosses.

Some members of the A-LAEF system were able to provide a correct forecast of the heavy precipitation in the areas of $\mathrm{C} 2$ or $\mathrm{C} 3$ or very close to them (Fig. 7, except the first row). There were no significant systematic differences between the forecasts of EPS members belonging to respective MP clusters. Thus, in this situation it is likely that the differences related to ESDA or stochastic physics had an impact on the precipitation distribution in the respective members rather than the choice of the physical parameterization. 


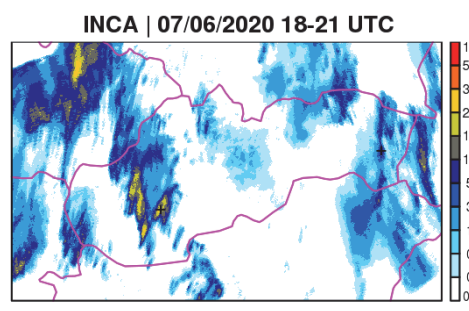

CONTROL | 18-21 UTC | MAX 58.71 mm

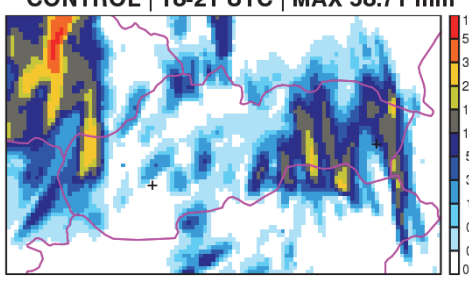

A-LAEF:03 | 18-21 UTC | MAX 107.38 mm

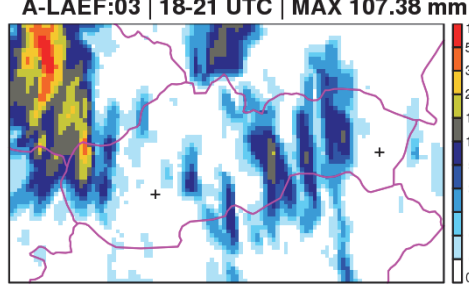

A-LAEF:06 | 18-21 UTC | MAX 73.42 mm

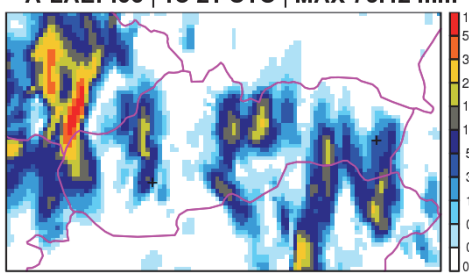

A-LAEF:09 | 18-21 UTC | MAX 65.89 mm

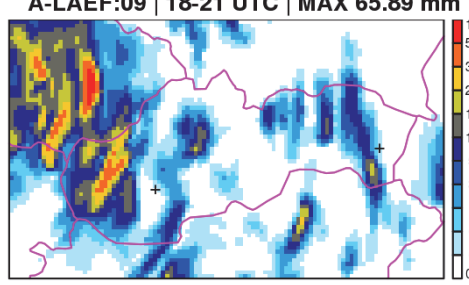

A-LAEF:12 | 18-21 UTC | MAX 49.36 mm

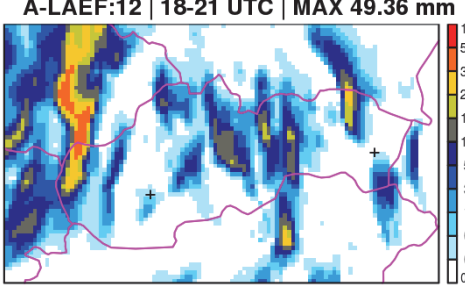

A-LAEF:15 | 18-21 UTC | MAX $71.57 \mathrm{~mm}$

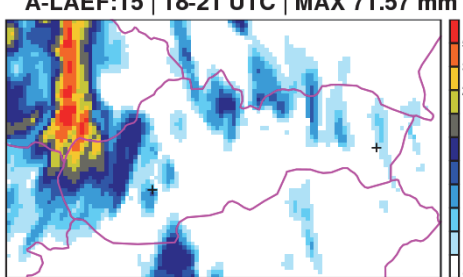

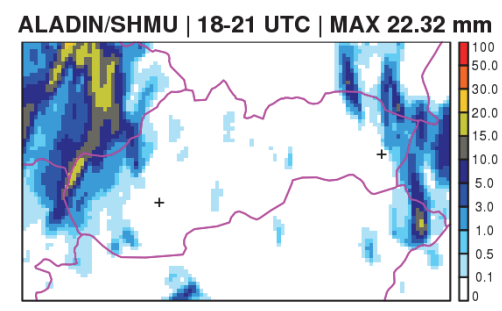

A-LAEF:01 | 18-21 UTC | MAX 95.5 mm

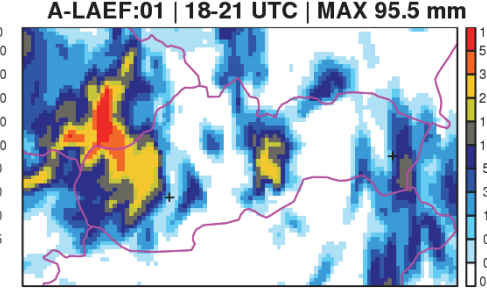

A-LAEF:04 | 18-21 UTC | MAX 71.91 mm

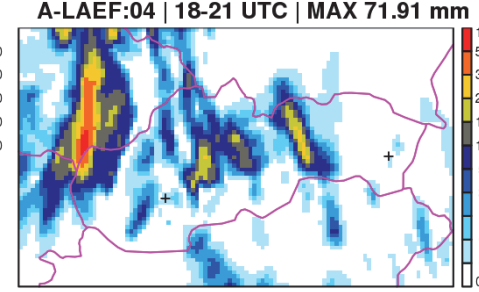

A-LAEF:07 | 18-21 UTC | MAX 46.77 mm

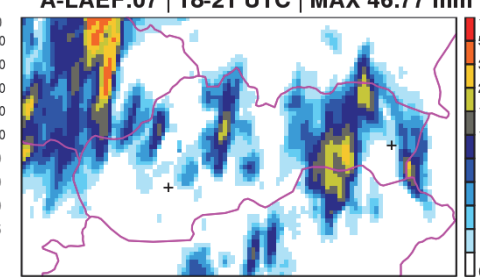

A-LAEF:10 | 18-21 UTC | MAX 51.04 mm

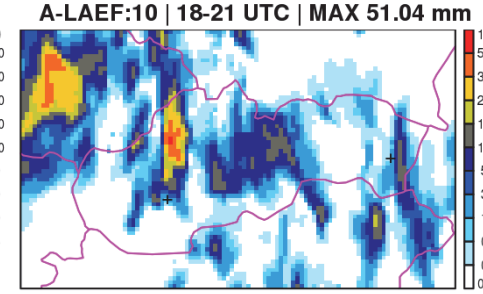

A-LAEF:13 | 18-21 UTC | MAX 60.28 mm

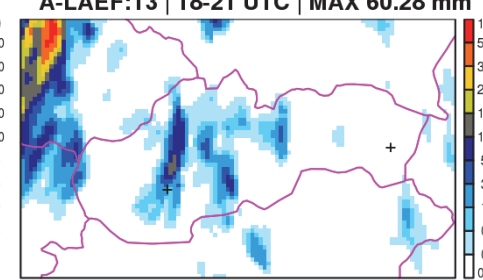

A-LAEF:16 | 18-21 UTC | MAX $64.67 \mathrm{~mm}$

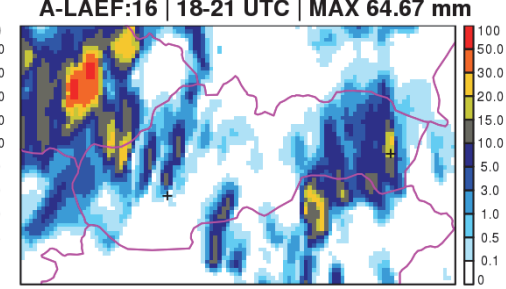

ALARO 2 | 18-21 UTC | MAX 32.76 mm

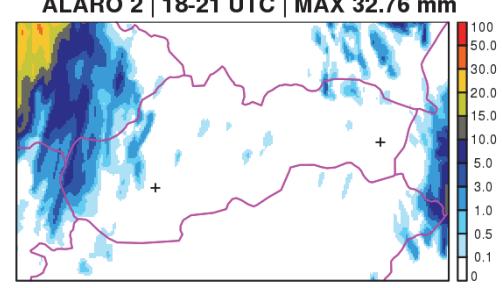

A-LAEF:02 | 18-21 UTC | MAX 51.47 mm

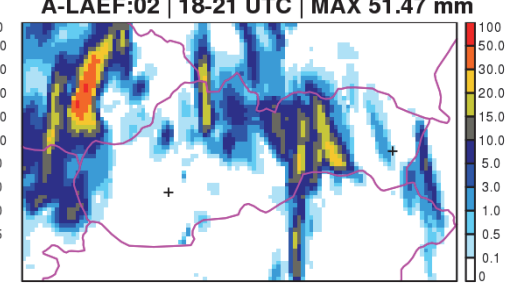

A-LAEF:05 | 18-21 UTC | MAX 57.12 mm

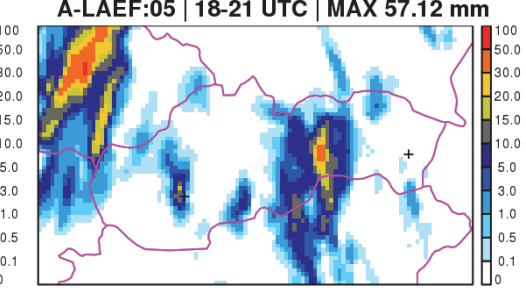

A-LAEF:08 | 18-21 UTC | MAX 53.55 mm

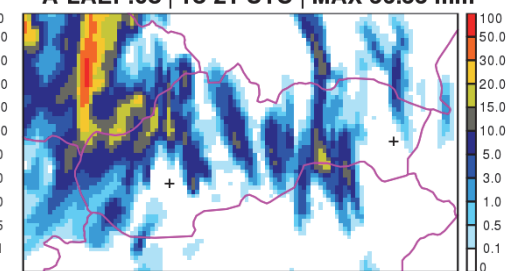

A-LAEF:11 | 18-21 UTC | MAX 87.14 mm

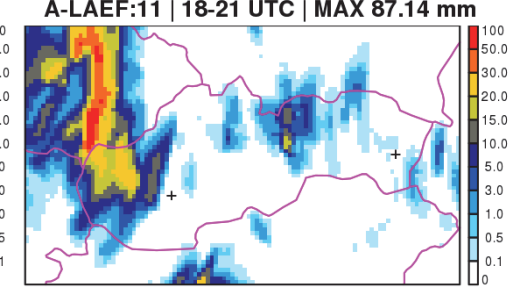

A-LAEF:14 | 18-21 UTC | MAX 45.34 mm

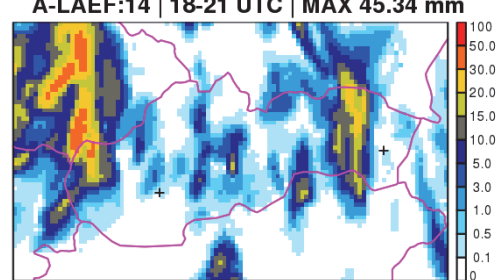

Fig. 7. 3-hourly precipitation accumulation [mm] of INCA analysis for June 7, 2020, 18-21 UTC period, corresponding forecasts of the operational ALADIN/SHMU and nonhydrostatic ALARO $2 \mathrm{~km}$ models based on the 12 UTC (first row), followed by the A-LAEF forecasts of EPS members based on the 12 UTC and valid for the same period as analysis. Several EPS members demonstrated the ability of forecasting precipitation near C2 and C3 related events at Tesárske Mlyňany and Michalovce (their position marked by crosses). 


\subsection{Probabilistic outputs and predictability of convective precipitation}

As it was already discussed in the previous subsection (Section 4.3), the probabilistic approach of the A-LAEF system was clearly more successful in predicting the convective event of June 7, 2020 than the operational deterministic model. This is especially true for the evening period, when the deterministic forecasts failed to generate strong enough convective activity. Even the reference non-hydrostatic ALARO 2 model with higher spatial resolution was too dry in eastern Slovakia, where in reality a high precipitation event $\mathrm{C} 3$ occurred (Fig. 7, third image in the first row). Among the ensemble members of A-LAEF system there were different scenarios. In some of them the eastern Slovakia was similarly without precipitation - e.g. members 04 and 13, while the other members captured the $\mathrm{C} 3$ event in correspondence with INCA analysis pretty well - particularly members $01,06,09$, 10, 14, 16 (Fig. 7). It can be concluded that small differences due to uncertainty simulation in the initial and boundary conditions as well as the stochastic perturbation of physics tendencies were the driving forces in this situation. Thus, taking into account the above-mentioned scenarios would be crucial for considering the predictability of this event. Furthermore, for June 7, 2020 situation it could be shown that along the convergence lines with highest assumed precipitation, there was also a high spread. While for the afternoon convection the spread was typically $5-10 \mathrm{~mm}$ along L1 (not shown) and the probability of at least low precipitation (exceeding $1 \mathrm{~mm}$ ) was $70-80 \%$ (Fig. 9, left), the spread was higher $(10-20 \mathrm{~mm})$ in case of the evening, prefrontal convection along L2 (Fig. 8, left). This was partially because of the more intense convection and higher EPS maxima (Fig. 8, right) but probably also due to higher uncertainty in forecasting the precipitation occurrence concerning this event (note that the forecasts of L2- and C3-related precipitation were of shorter range than that of L1). The probability of precipitation exceeding $1 \mathrm{~mm}$ was mostly below $50 \%$ in the vicinity of L2 and C2, despite the high precipitation forecast by some EPS members (Fig. 9, right).
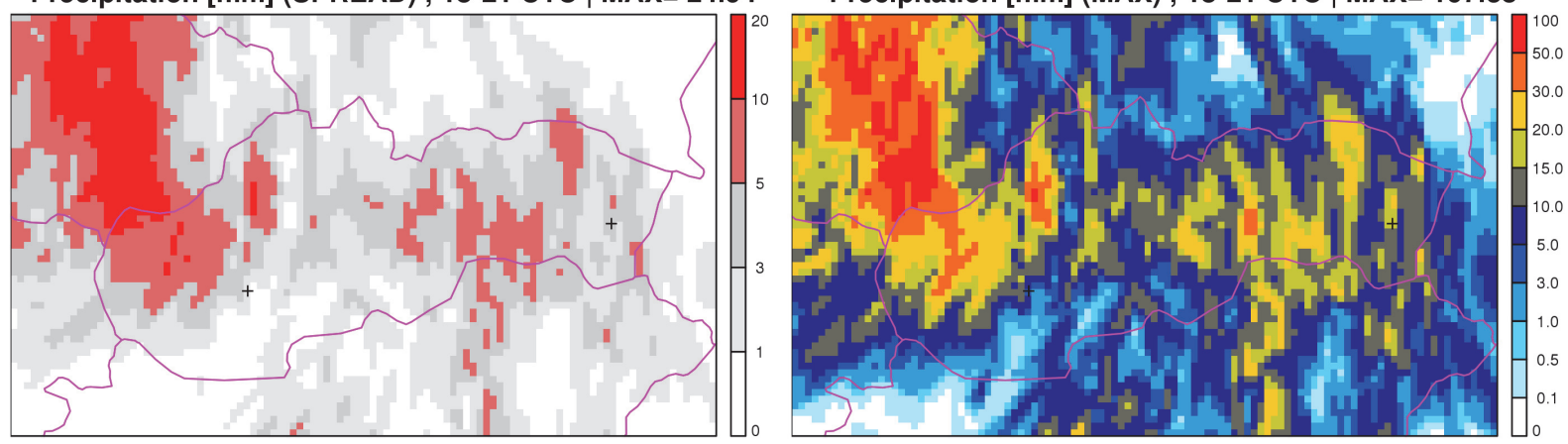

Fig. 8. Forecast of the A-LAEF EPS system based on June 7, 2020, 12 UTC and valid for the 18-21 UTC period: 3-hourly precipitation spread [mm] (left), EPS maximum of 3hourly accumulated precipitation [mm] (right). 


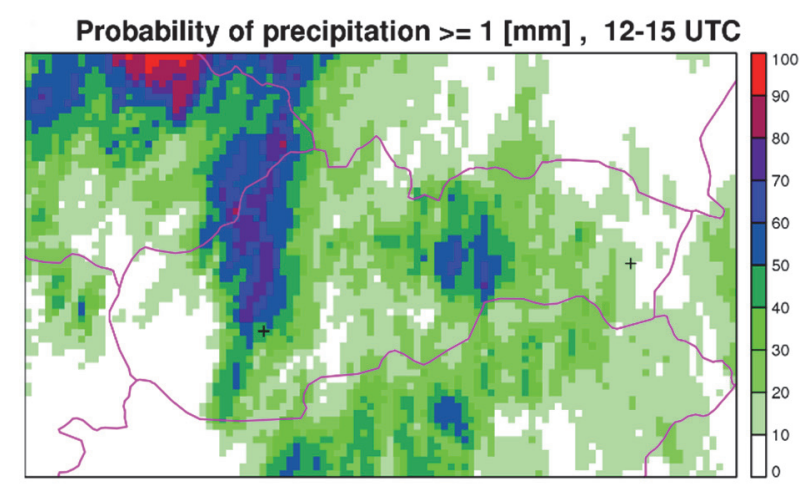

Probability of precipitation >= $1[\mathrm{~mm}], 18-21$ UTC

Fig. 9. Probability of precipitation for $1 \mathrm{~mm}$ threshold based on the A-LAEF EPS forecast from June 7, 2020, 00 UTC valid for the 12-15 UTC period (left), and from 12 UTC valid for the 18-21 UTC period (right).

\subsection{Convection-permitting experiments}

\subsubsection{Dynamics optimization (from stability and performance perspective)}

The experiments listed in Tables 2 and 4 are described in this subsection. As it can be seen in Fig. 10, the SI SETTLS scheme was stabilized using NHHY parameters set to 1.2 at resolution $2 \mathrm{~km}$ (ID01). The overall character of the solution is the same as the one computed with ICI reference (ID00). First row presents the $3 \mathrm{~h}$ precipitation forecast from June 7, 2020 at 00 UTC for 12-15 h. There is no signal that would indicate instability in the solution. The green line on precipitation maps shows the direction of the vertical cross section via the line of convective cells. The cross sections are shown in the second row of Fig. 10. The structure of the cell is consistent in both experiments. The order of differences is typical for this kind of modification in advanced NWP systems, where complex feedback mechanisms are taking place under small forcing, especially in convective situations.

The same experiments were carried out with a $1 \mathrm{~km}$ version of the model as well (IH00 and IH01). The NHHY scheme was stable as well. The results are not presented here as qualitatively they were not relevant, because the physical parameterizations are scale-dependent and would require tuning, which was out of scope of this paper. 

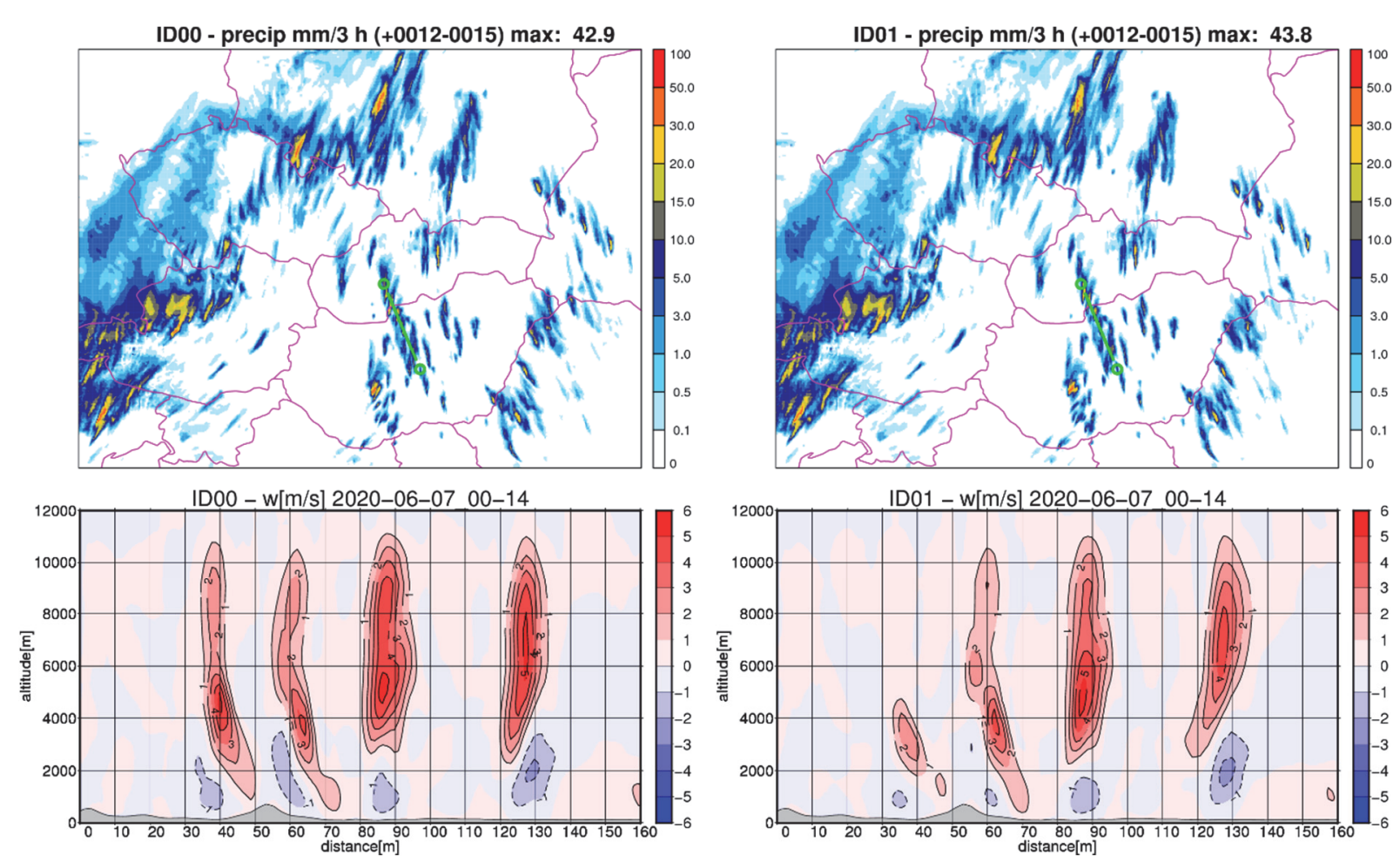

Fig. 10. The first column contains forecasts obtained with the reference ICI scheme and the second column with the NHHY scheme. In the first row, 3-hourly precipitation accumulation [mm] for June 7, 2020 is presented, 12-15 UTC period, left: ID00 with ICI scheme, right: ID01 with the NHHY scheme. The vertical cross section via convective cells (shown by green line in first row pictures) is at the second row.

\subsubsection{Structure and evolution of convective cells}

The non-hydrostatic experiments focused mainly on small-scale (meso-gamma) features, of which some could be observed on the radar imagery, mainly in the 12-15 UTC period (notably the $\mathrm{C} 1$ cell). The model runs produced several individual convective cells exhibiting $2-5 \mathrm{~m} / \mathrm{s}$ vertical velocities at $700 \mathrm{hPa}$ (extremes were up to $7 \mathrm{~m} / \mathrm{s}$ in the levels above) and 2-3 m/s downdrafts. An intense and relatively persistent (could be traced between 11:50 and 13:30 UTC) updraft formation moved from Hungary toward southern Slovakia (Fig. 11, left). Initially, it was a cluster of several individual cells aggregating into one (not shown). The closest strong and relatively stable pattern in the radar reflectivity field was the C1 (Fig. 11, right), which could have also consisted of several updrafts. It could also have a WER (weak echo region) signature on its northwestern flank (could be seen as a shallow cave in the reflectivity field on several CAPPI $3 \mathrm{~km}$ images). Such signatures, when persistent, are sometimes associated with stronger updrafts or mesocyclonic circulation and inflow of the unsaturated environmental air (Moller et al., 1994). One could see such 
circulation in both storm-relative wind and vorticity fields in the vicinity of the strongest updrafts of the simulated cells, at mid-levels (mostly 700 and $500 \mathrm{hPa}$ ). The cyclonic vorticity was accompanied by lower geopotential (Fig. 12, left). For $\mathrm{C} 1$, one could identify weak azimuthal shear in the field of the radial Doppler velocity, close to the assumed WER signature (Fig. 12, right). Velocity differences of $5 \mathrm{~m} / \mathrm{s}$ on $5 \mathrm{~km}$ distance were inferred between local maxima and minima, which corresponds to shear of about $0.001 \mathrm{~s}^{-1}$. Not taking into account some noisy artifacts in the Doppler velocity, this shear could be rather a consequence of a weak cyclonic circulation than a supercellar MVS (mesocyclonic vorticity signature), which usually exhibits of about one order stronger shear (AMS Glossary of Meteorology, 2000). Similarly, the magnitude of vorticity of the simulated vortex was below $0.005 \mathrm{~s}^{-1}$, and it could possibly be a kind of mesovortex (Weisman and Trapp, 2003) but rather confined to mid-levels. The simulated convection did not always propagate as an organized system, but new updrafts and cells were generated at the flanks of the downdrafts of older cells. For the investigated convective feature, a line of new updrafts emerged on the western and northern flanks of its outflow (Fig. 13, left). However, development of new rain patterns was rather sparse in the westward direction (not shown). On the radar imagery, one could see a line of new but weak cells westward of $\mathrm{C} 1$ (Fig. 13, right). These cells quickly decayed, probably as a result of unfavorable humidity and shear conditions over southwestern Slovakia.

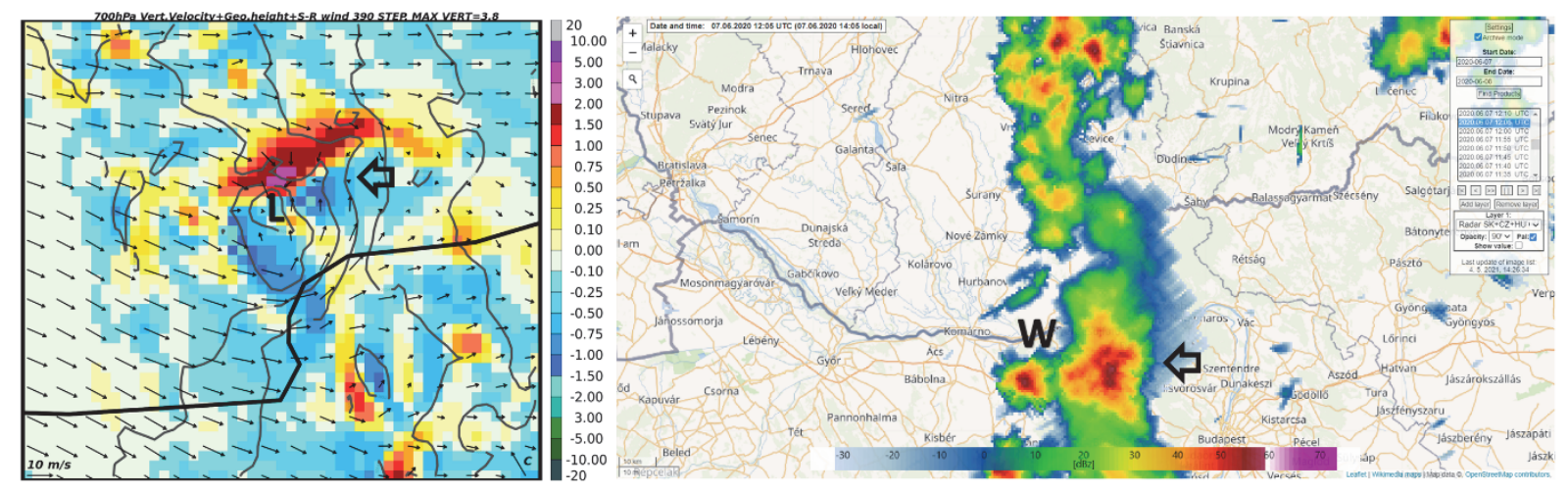

Fig. 11. Left: forecast of the ALARO 2 of the June 7,2020, 00 UTC run showing the field of $700 \mathrm{hPa}$ vertical velocity (shades, $\mathrm{m} / \mathrm{s}$ ), geopotential height (lines, by $2 \mathrm{gpm}$ ), and stormrelative wind $(\mathrm{m} / \mathrm{s})$ valid for 13 UTC. The vector denoted "c" in the lower right corner depicts the storm motion vector. Right: CAPPI $3 \mathrm{~km}$ radar reflectivity $(\mathrm{dBz})$ on June 7 , 2020, 12:05 UTC. The arrow points toward the position of cell C1 defined by the vertical velocity on the left and toward the radar reflectivity maxima on the right. Letter $\mathrm{W}$ indicates the position of WER-like echo at the northwestern flank of $\mathrm{C} 1$. L highlights the local low in the geopotential field. 

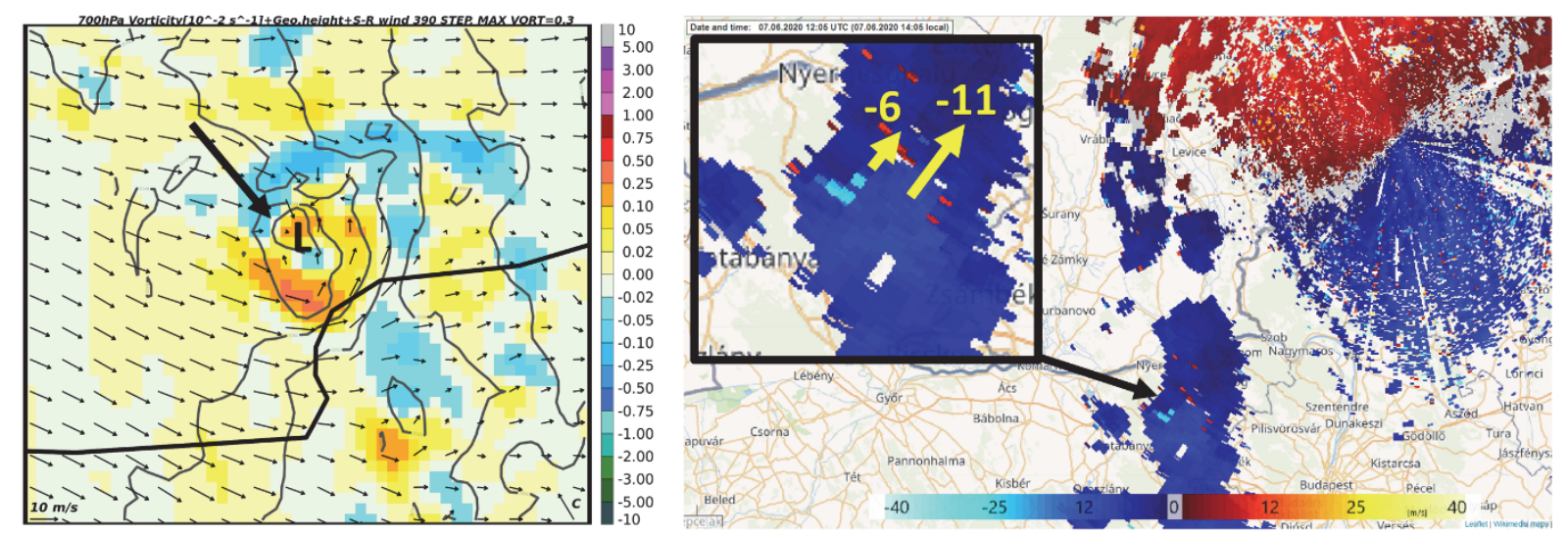

Fig. 12. Left: forecast of the ALARO 2 of the June 7, 2020, 00 UTC run showing the field of $700 \mathrm{hPa}$ vertical vorticity (shades, $10^{-2} \mathrm{~s}^{-1}$ ), geopotential height (lines, by $2 \mathrm{gpm}$ ), and storm-relative wind $(\mathrm{m} / \mathrm{s})$ valid for 13 UTC. Right: PPI $1.0^{\circ}$ radial Doppler velocity $(\mathrm{m} / \mathrm{s})$ on June 7, 2020, 12:05 UTC. The arrow points toward the center of cyclonic circulation on the left and toward cyclonic shear in the radial Doppler velocity field on the right. Meaning of $\mathrm{L}$ as in Fig. 11. The enlarged detail depicts the region of azimuthal shear found in $\mathrm{C} 1$ in the Doppler velocity field (indicated by vectors and values in $\mathrm{m} / \mathrm{s}$ ).
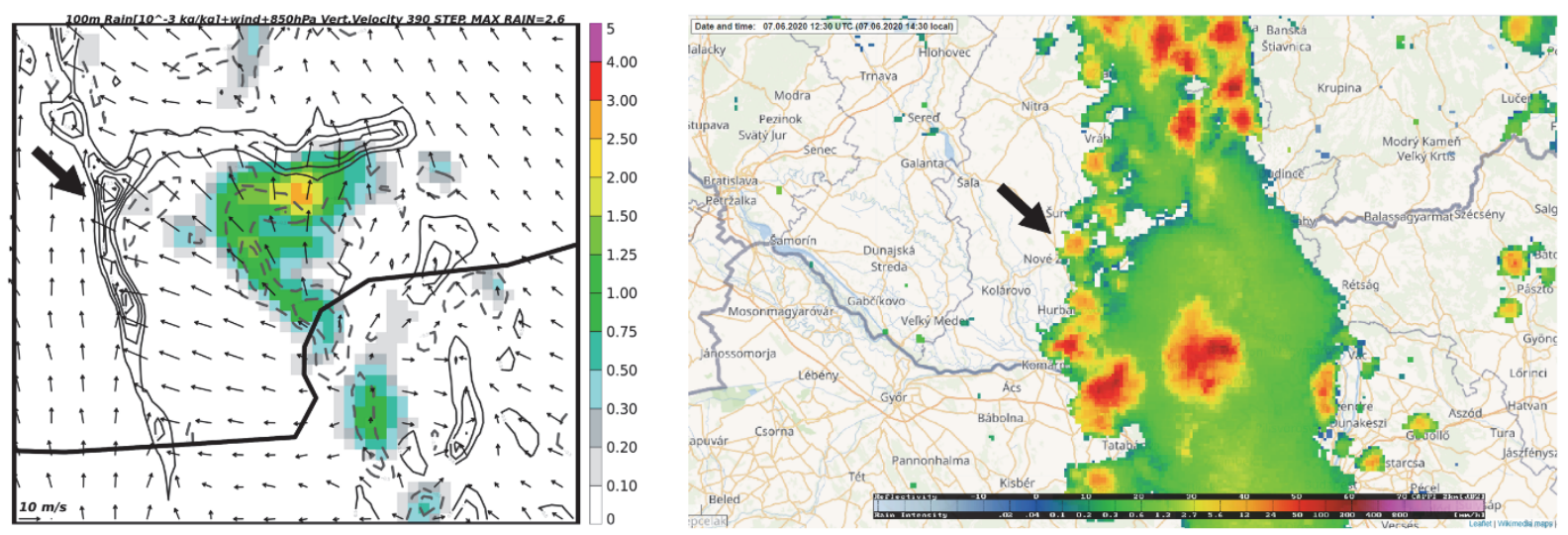

Fig. 13. Left: forecast of the ALARO 2 of the June 7, 2020, 00 UTC run showing the field of rain mixing ratio (shades, $10^{-3} \mathrm{~kg} / \mathrm{kg}$ ), $850 \mathrm{hPa}$ vertical velocity (lines by $0.5 \mathrm{~m} / \mathrm{s}$, solid - updrafts, dashed - downdrafts), and $100 \mathrm{~m}$ wind $(\mathrm{m} / \mathrm{s})$ valid for 13 UTC. Right: Cmax radar reflectivity $(\mathrm{dBz})$ on June 7, 2020, 12:30 UTC. The arrow points toward a line of updrafts generated on the leading edge of the cell outflow on the left, and a line of new cells emerging (and then quickly decaying) on the western flank of $\mathrm{C} 1$ on the right.

\subsubsection{Comparison with satellite imagery}

The speed of vertical growth of convective clouds depends on the intensity of their updrafts and vertical velocity, especially close to the top of the clouds. On the satellite imagery, the evolution of convection can be followed on the infrared 
channels and CTB. The latter parameter is not exactly the temperature of the environment, but it largely depends on the air temperature at the same level (Hanna et al., 2008). In fast evolving clouds with higher vertical velocities, the cooling of CTB is generally also faster. It was expected that in case that the magnitude of vertical velocities in the simulated clouds is similar to the real ones, one should also observe nearly similar CTT and CTB trends. The CTB and CTT comparison is reasonable during the rising phase of the convective cloud (thunderstorm), until it reaches its top and an anvil cloud is created. In case there is already a high cloudiness (cirrus clouds), the determination of the cloud top cooling rate becomes more difficult or not possible at all. There are also other limitations such as the resolution of the satellite imagery, which currently makes it difficult to trace the very early (cumulus) stage of the clouds.

For comparison, we selected rather isolated (not necessarily the most intense!) convective clouds on the satellite imagery, which had their counterparts in the SWDIAG experiment (developing at nearly the same time and place). An example was the convection over the southern part of central Slovakia, close to the Hungarian border (Fig. 14, left). The CTB of its clouds could be determined at 10:50 UTC, when it was $-15^{\circ} \mathrm{C}$, and it reached its minimum $\left(-55^{\circ} \mathrm{C}\right)$ at $11: 45 \mathrm{UTC}$ (Fig. 14, right). According to the 12 UTC Budapest sounding, this temperature would be close to the air temperature at the tropopause (at $11 \mathrm{~km}$ height). The evolution of a similar cell in the model forecast started somewhat later (similar CTT as the satellite CTB appeared around 11:00 UTC). The minimum CTT (-53 ${ }^{\circ} \mathrm{C}$ ) was reached in the mature stage of the cell and appeared 25 minutes later compared to CTB. The best agreement between CTT and CTB rate of cooling was in the temperature interval between $-20{ }^{\circ} \mathrm{C}$ and $-40{ }^{\circ} \mathrm{C}$. Also in case of other cells (e.g., within L1) it could be seen, that the model cooling of the CTT is faster in the early stage of deep convection (i.e., the first 15-20 minutes of evolution) and it slowed down after, while opposite behavior was observed for the CTB course. Apart from technical reasons, this could also be related to the local environment and vertical distribution of buoyancy (e.g., presence of shallow inversions or stable layers, which slow down the growth of the thunderstorm clouds and which are often absent in the NWP forecasts). 

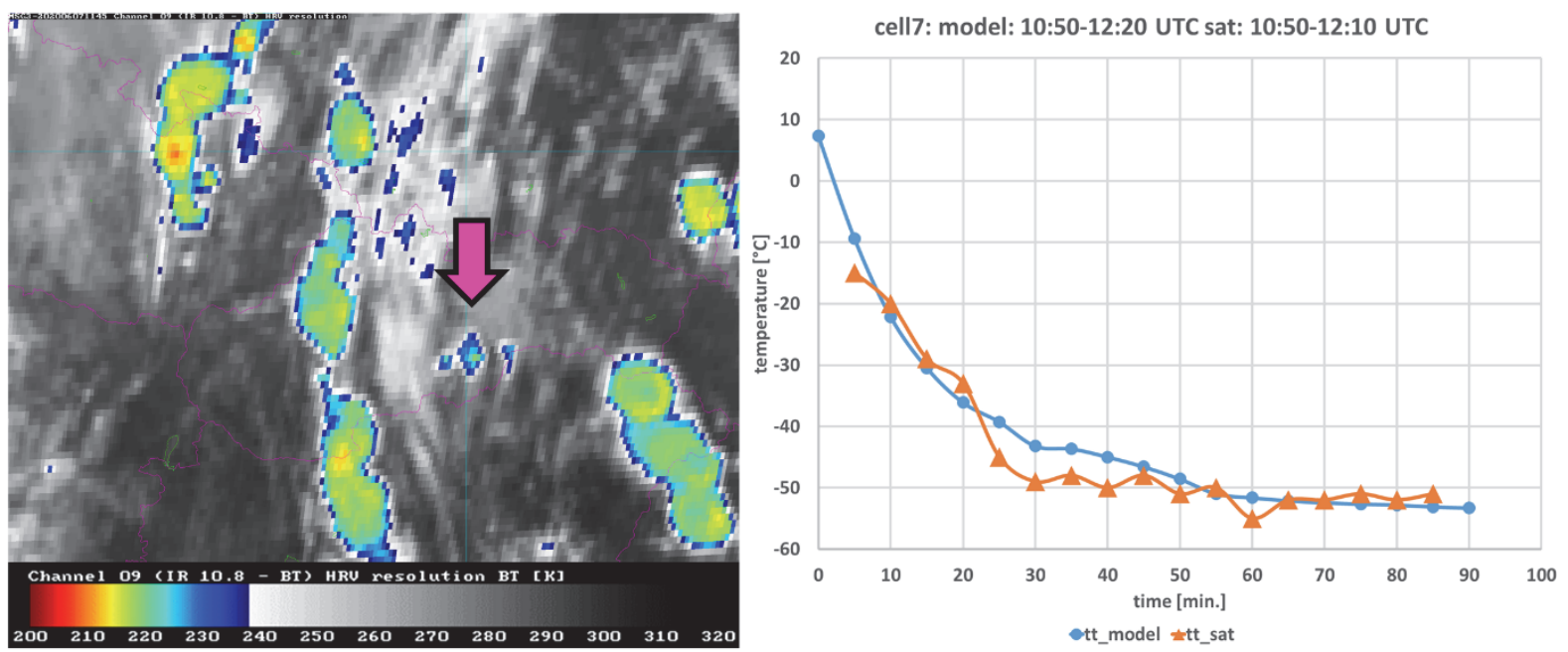

Fig. 14. Left: brightness temperature (K) from Meteosat 10 infrared $10.8 \mu \mathrm{m}$ channel over Slovakia on June 7, 2020, 11:45 UTC. The arrow points toward the convective cloud, of which the cloud-top temperature evolution was studied. Right: time-evolution of modelbased cloud top temperature CTT in ${ }^{\circ} \mathrm{C}$ (blue line with circles) and satellite-based brightness temperature $\mathrm{CTB}$ in ${ }^{\circ} \mathrm{C}$ (orange line with triangles) of the cloud shown on the left. Both CTT and CTB curves start at 10:50 UTC. In the model, the evolution of a similar cell as investigated in the satellite imagery was delayed, but both curves were transposed in order to compare the rapid development phase of the convective cloud.

\section{Conclusion and perspectives}

In the presented situation, multicellular convection developed, occasionally causing severe weather. Especially point forecasts of such events is challenging, because the distribution of precipitation is very uneven, convection forms along relatively narrow convergence lines, which sometimes cannot be defined with sufficient precision in the model (due to the influence of orography but also outflows of previous convective cells and systems). Deterministic forecasting of heavy precipitation in such cases is difficult either by hydrostatic or higher resolution non-hydrostatic models - this is illustrated also by the fact that several model runs failed to forecast precipitation along the L2 line or near $\mathrm{C} 3$ even in very short time-range and despite favorable environment for deep convection.

In the presented case study, the initiation of convection has been better specified with enhanced assimilation of high resolution data from various sources, whose positive impact (bigger number of patterns, more intense precipitation) could be observed even after more than $18 \mathrm{~h}$ of integration (here illustrated only up to $15 \mathrm{~h}$ ). Further improvement could be obtained with an advancement of the data assimilation setup. Ongoing work on the BLENDVAR configuration comprises diagnostics of observation and background error statistics according to Desroziers et al. (2005), increase of the analysis frequency, and employment of other types of observations. Revision of the background error statistics derivation 
according to Bučánek and Brožková (2017) is planned as well when more HPC resources are available.

In the current study, even improved data assimilation or change of the lateral boundary conditions were mostly not sufficient to define the exact position of major convergence lines or the intensity of the heaviest precipitation. The nonhydrostatic dynamic adaptations based on ALARO 2 led to finer precipitation structures but did not substantially correct their position with respect to outputs of their driving hydrostatic models. Moreover, initiation of convective cells in nonhydrostatic models seems to be even more complicated - dependent not only on the environment but also on the interactions of the simulated cells and their outflows. Even if deep convection had developed, the resulting precipitation was often too weak with respect to both observation and precipitation parameterized by hydrostatic models. This could be also due to parameterizations setup in the non-hydrostatic models (e.g., for microphysics), for which further investigation is planned in the near future on more cases with deep convection and was only marginally studied here.

The forecasts of the A-LAEF system provided the most exact location of precipitation along lines L1 or L2, and several EPS members succeeded also to forecast local intense rainfall related to $\mathrm{C} 2$ and $\mathrm{C} 3$ cells. Comparison of results from respective MP clusters indicates that the influence of different setups of physical parameterization did not have a systematic effect (on the contrary to some other weather situations, e.g., winter temperature inversion, not presented here). More impact could be expected in relation with ESDA assimilation or application of stochastic perturbation, which possibly imitate local effects important for the initiation of deep convection and are absent in the deterministic model runs. The A-LAEF also provided useful information about the forecast uncertainty, which was particularly high for the heavy precipitation events. The probability of precipitation exceeding $10 \mathrm{~mm}$ was rarely bigger than $40 \%$. Such outputs, even if correct, could be possibly underestimated by non-experts. Surveys among users (e.g., from civil protection) indicate that they prefer rather high probability thresholds to take measures, mostly above $50 \%$ chance of occurrence (Kox and Ulbrich, 2015). An issue to be investigated in the future is whether a bigger ensemble could possibly specify the local distribution of high precipitation with better precision and improve the forecast confidence.

The structure and evolution of convection simulated in the experiments with non-hydrostatic dynamics showed some traits similar to radar observations. Weak mesoscale vortices, which developed in the model in the vicinity of the most intense cells could exist in some significant thunderstorms (e.g., in the cell C1). Previous studies (e.g., Csirmaz et al., 2013) suggested that mesocyclones can develop even in a weak-shear environment, although these vortices are sometimes confined only to a relatively shallow layer of the low- or mid- troposphere. Yet, it is uncertain whether these vortices also play a substantial role in the life cycle of these thunderstorms (e.g., concerning their longevity). One could also observe 
similar multicellular behavior as in the observations, e.g., development of new updrafts on the outflow boundaries of older storms. However, the updrafts in the simulations were often relatively weak (in order of only a few $\mathrm{m} / \mathrm{s}$ ), though one should consider that these velocities represent an average in the given $2 \times 2 \mathrm{~km}$ grid box. The CAPE values would indicate much higher (well exceeding $10 \mathrm{~m} / \mathrm{s}$ ) maximum updraft velocities, which are usually present either in observed or simulated multicell thunderstorms in other studies, even in weak shear conditions (Kirkpatrick et al., 2009; Fovell and Dailey, 1995; Fovell and Tan, 1998). It is possible that the weaker updrafts in the ALARO 2 model simulations had also a consequence of underestimation of precipitation and lack of convection in certain areas (e.g., northwest Slovakia, southern Poland), but this would need further investigation.

The possibility of simulating the convection explicitly also raises the question of how to verify the magnitude of vertical velocity of convective cells generated in the model, which is usually not measured directly. One way is to compare the evolution of model clouds and their properties (e.g., cloud top temperature) with the rapidly updated satellite imagery. However, this is possible rather in case of isolated cells and despite some promising results, there are still large uncertainties in the algorithm concerning the microphysical properties of cloudiness at the top of the thunderstorms and its distinguishing from ordinary, non-convective cirrus clouds. Similarly, the determination of satellite CTB is also limited due to current resolution of the infrared imagery, which will be improved after launching the Meteosat Third Generation satellite (MTG).

Further progress in calculation efficiency of non-hydrostatic models is inevitable, as well as the stability of such computation. It was shown that the semiimplicit scheme with NHHY formulation could help to fulfil such goals being significantly faster than the current iterative centered implicit scheme. The execution times of $15 \mathrm{~h}$ forecast are shown in the Table 4. The relative speedup of model execution with NHHY scheme is $20 \%$ for the $1 \mathrm{~km}$ resolution experiment and $28 \%$ for the $2 \mathrm{~km}$ resolution one. Therefore, NHHY approach allows large improvement of execution efficiency at model resolutions around 2-1 km, and it potentially opens the possibility to run convection-permitting EPS systems also at meteorological centers where medium size HPC systems are installed. Certainly, more tests are needed in future in other conditions and different types of severe weather (including mesoscale convective systems and supercells) or even on continuous periods of time to examine the robustness of the new scheme and prediction capabilities of the non-hydrostatic version of ALARO.

All the above mentioned activities should be joined in the future in a form of convection-permitting EPS, using data assimilation with high resolution observations, run at short range and on sufficiently large domain (similarly to the current ALADIN/SHMU). 
Acknowledgements: This publication is partially a result of the project implementation: „Scientific support of climate change adaptation in agriculture and mitigation of soil degradation" (ITMS2014+ 313011W580) supported by the Integrated Infrastructure Operational Programme funded by the ERDF. The work on the A-LAEF system, on the assimilation of radial wind velocities and on the nonhydrostatic dynamics was partially executed during the RC LACE research stays. Colleagues from CHMI are acknowledged for useful discussions and comments.

Experts from SHMÚ profited greatly in previous decades from the supervision and mentoring of experienced Hungarian colleagues during stays in Meteo-France and at OMSZ. Our first variational data assimilation experiments were performed with OMSZ technical help. Our operational data assimilation relies on the OPLACE backbone for provision of observation data operated by OMSZ.

We are grateful to two anonymous reviewers for their valuable remarks and suggestions leading to overall text improvement.

\section{References}

AMS Glossary of Meteorology, 2000: Mesocyclone (visited on 7 May 2021), Website https://glossary.ametsoc.org/wiki/Mesocyclone

Baldauf, M., A. Seifert, J. Förstner, D. Majewski, M. Raschendorfer, and T. Reinhardt, 2011: Operational convective-scale numerical weather prediction with the COSMO model: Description and sensitivities. Mon. Weather Rev. 139, 3887-3905. https://doi.org/10.1175/MWR-D-10-05013.1.

Belluš, M., Y. Wang, and F. Meier, 2016: Perturbing surface initial conditions in a regional ensemble prediction system. Mon. Weather Rev. 144, 3377-3390. https://doi.org/10.1175/MWR-D-16-0038.1.

Belluš, M., F. Weidle, C. Wittmann, Y. Wang, S. Taşku, and M. Tudor, 2019: Aire Limitée Adaptation dynamique Développement InterNational - Limited Area Ensemble Forecasting (ALADINLAEF). Adv. Sci. Res. 16, 63-68. https://doi.org/10.5194/asr-16-63-2019

Belluš, M., 2019: Uncertainty simulation in ALADIN-LAEF, Presentation, ALARO-1 Working days 2019, Bratislava, Slovakia, 11-13 March 2019. https://www.rclace.eu/File/ALARO/alaro1_wd19br/alaro1wd_MB_laef_mar19.pdf

Belluš, M., 2020a: New high-resolution ensemble forecasting system A-LAEF (in Slovak with English abstract). Met. J. Slovak Hydromet. Inst. 23, 75-86.

Belluš, M., 2020b: LAM-EPS activities in LACE, Presentation, Joint 30th ALADIN Workshop and HIRLAM ASM 2020, 30/03-03/04/2020, visio-conference.

http://www.umr-cnrm.fr/aladin/IMG/pdf/2020_04_ahw_online_eps_mbell.pdf

Bénard, P., 2003: Stability of semi-implicit and iterative centered-implicit time discretizations for various equation systems used in NWP. Mon. Weather Rev. 131, 2479-2491. https://doi.org/10.1175/1520-0493(2003)131<2479:SOSAIC>2.0.CO;2.

Bénard, P., 2004: On the use of a wider class of linear systems for the design of constant-coefficients semi-implicit time schemes in NWP. Mon. Weather Rev. 132, 1319-1324. https://doi.org/10.1175/1520-0493(2004)132<1319:OTUOAW>2.0.CO;2.

Bénard, P., Vivoda, J., Mašek, J., Smoliková, P., Yessad, K., Smith, C., Brožková, R., and Geleyn, J. F., 2010: Dynamical kernel of the Aladin-NH spectral limited-area model: Revised formulation and sensitivity experiments. Quart. J. Roy. Meteor. Soc. 136, 155-169. https://doi.org/10.1002/qj.522

Bengtsson, L., Andrae, U., Aspelien, T., Batrak, Y., Calvo, J., de Rooy, W., Gleeson, E., Hansen-Sass, B., Homleid, M., Hortal, M., Ivarsson, K.-I., Lenderik, G., Niemelä, S., Nielsen, K. P., Onvlee, J., Rontu, L., 880 Samuelsson, P., Muñoz, D. S., Subias, A., Tijm, S., Tol, V., Yang, X., and Køltzow, M. Ødegaard., 2017: The HARMONIE-AROME model configuration in the ALADIN-HIRLAM NWP system. Mon. Weather Rev., 145, 1919-1935. https://doi.org/10.1175/MWR-D-16-0417.1.

Bouttier, F., Vie, B. Nuissier, O., and Raynaud, L., 2012: Impact of stochastic physics in a convectionpermitting ensemble. Mon. Weather Rev 140, 3706-3721.https://doi.org/10.1175/mwr-d-12-00031.1. 
Brousseau, P., Seity, Y., Ricard, D., and Léger, J., 2016: Improvement of the forecast of convective activity from the AROME-France system. Quart. J. Roy. Meteor. Soc. 142, 2231-2243. https://doi.org/10.1002/qj.2822

Brožková, R., Bučánek, A., Mašek, J., Smolíková, P., and Trojáková, A., 2019: Nová provozní konfigurace modelu Aladin ve vysokém rozlišení. Meteorologické zprávy 72, 129 139.http://www.cmes.cz/sites/default/files/chmu_mz_5-19_129-139.pdf(In Czech)

Brožková, R., Bučánek, A., Mašek, J., Němec, D., Smolíková, P., Šábik, F., and Trojáková, A., 2021: Numerical weather prediction activities at CHMI., ACCORD $1^{\text {st }}$ AWS videoconference, 12-16 April 2021, poster presentation. https://doi.org/10.22233/20412495.0421.1

Bučánek, A., Brožková R., and Trojáková, A., 2015: Asimilační schéma BlendVar v ČHMÚ. Meteorologické zprávy 68, 180-185. (in Czech) https://www.chmi.cz/files/portal/docs/reditel/SIS/casmz/assets/2015/chmu_mz_6-15.pdf

Bučánek, A. and Brožková, R., 2017: Background error covariances for a BlendVar assimilation system. Tellus A 69, DOI: 10.1080/16000870.2017.1355718

Cedilnik, J., 2005: Parallel suites documentation. Regional Cooperation for Limited Area Modeling in Central Europe Rep. 2.http://www.rclace.eu/File/Physics/2005/cedilnik_stay_2005.pdf.

Csirmaz, K., Simon, A., Pistotnik, G., Polyánszky, Z., Neštiak, M., Nagykovácsi, Z. and Sokol, A., 2013: A study of rotation in thunderstorms in a weakly- or moderately-sheared environment. Atmos. Res. 123, 93-116. https://doi.org/10.1016/j.atmosres.2012.09.017

Čatlošová, K. and Derková, M., 2020: Exploitation of aircraft Mode-S data in AROME/SHMU numerical weather prediction model. Meteorologický časopis 23 65-74. http://www.shmu.sk/File/ExtraFiles/MET CASOPIS/MC 2020-2.pdf.

Čatlošová, K., 2020: Assimilation of radial velocity from radars. RC LACE stay report, available at www.rclace.eu.https://www.rclace.eu/File/Data_Assimilation/2020/repStay_KCatlosova_Radi alWindAssimilaton_2020_07.pdf

Derková, M., 2005: Numerical Weather Prediction Activities at the Slovak Hydrometeorological Institute. Meteorol. J. 8, 53-64.

Derková, M. and Belluš, M., 2007: Various applications of the blending by digital filter technique in the ALADIN numerical weather prediction system. Meteorologický časopis 10, 27-36.

Derková, M., Vivoda, J., Belluš, M., Španiel, O., Dian, M., Neštiak, M., Zehnal, R., 2017: Recent improvements in the ALADIN/SHMU operational system. Meteorologický časopis Vol. 20 No. 2, 45-52. (in Czech) http://www.shmu.sk/File/ExtraFiles/MET_CASOPIS/2017-2_MC.pdf.

Desroziers, G., Berre, L., Chapnik, B. and Poli, P., 2005: Diagnosis of observation, background and analysis-error statistics in observation space. Quart. J. Roy. Meteorol. Soc. 131, 3385-3396. https://doi.org/10.1256/qj.05.108

Dorog-Esztergom Időjárása, 2020: Özönvíz zúdult térségünk nyugati felére vasárnap délután (In Hungarian), Website (Visited on 07 May 2021), https://dorog-esztergomidojarasa.hu/hirek/ozonviz-zudult-tersegunk-tobb-pontjara-vasarnap-delutan/

Durán, I. B., Geleyn, J., and Ván̆a, F., 2014: A Compact Model for the Stability Dependency of TKE Production-Destruction-Conversion Terms Valid for the Whole Range of Richardson Numbers. J. Atmos. Sci. 71, 3004-3026. https://doi.org/10.1175/JAS-D-13-0203.1

Durán, I. B., 2014: Toucans. RCLACE stay report, Bratislava, 5 April - 2 May 2013, 12. http://www.rclace.eu/File/Physics/2014/bastakduran_toucans_bratislavaMay2014.pdf

Ďurán, I. B., Geleyn, J., Váňa, F., Schmidli, J., and Brožková, R., 2018: A Turbulence Scheme with Two Prognostic Turbulence Energies. J. Atmos. Sci. 75, 3381-3402. https://doi.org/10.1175/JAS-D-18-0026.1

ESTOFEX: 2020, Website: https://www.estofex.org/ (visited on 10 May 2021)

European Severe Weather Database, 2020: Website (visited on 7 May 2021).https://www.eswd.eu/

Fischer, C. and Auger, L., 2011: Some experimental lessons on digital filtering in the ALADIN-France 3DVAR based on near-ground examination, Mon. Weather Rev. 139, 774-785. https://doi.org/10.1175/2010MWR3388.1

Fovell, R. G. and Dailey, P. S., 1995: The temporal behavior of numerically simulated multicell-type storms. Part I: Modes of behavior. J. Atmos. Sci. 52, 2073-2095. https://doi.org/10.1175/1520-0469(1995)052<2073:TTBONS >2.0.CO;2 
Fovell, R. G. and Tan, P.-H., 1998: The temporal behavior of numerically simulated multicell-type storms. Part II: The convective cell life cycle and cell regeneration. Mon. Weather Rev. 126, 551- 577.

Geleyn, J.-F., Váňa, F., Cedilnik, J., Tudor, M., and Catry, B., 2006: An intermediate solution between diagnostic exchange coefficients and prognostic TKE methods for vertical turbulent transport. In (Ed: Côté, J.) CAS/JSC WGNE "Blue Book" annual report: Research Activities in Atmospheric and Ocean Modelling. 4.11-4.12.

Gerard, L., Piriou, J.-M., Brožková, R., Geleyn, J.-F., and Banciu, D., 2009: Cloud and precipitation parameterization in a meso-gamma scale operational weather prediction model. Mon. Weather Rev. 137, 3960-3977. https://doi.org/10.1175/2009MWR2750.1

Gustafsson, N., Janjić, T., Schraff, C., Leuenberger, D., Weissmann, M., and co-authors. 2018: Survey of data assimilation methods for convective-scale numerical weather prediction at operational centres. Quart. J. Roy. Meteorol. Soc. 144, 1218-1256. https://doi.org/10.1002/qj.3179.

Giard, D. and Bazile, E., 2000: Implementation of a New Assimilation Scheme for Soil and Surface Variables in a Global NWP Model. Mon. Weather Rev. 128, 997-1015. https://doi.org/10.1175/1520-0493(2000)128<0997:IOANAS $>2.0 . C O ; 2$

Haiden, T., Kann, A., Wittmann, C., Pistotnik, G., Bica, B., and Gruber, C., 2011 The integrated nowcasting through comprehensive analysis (INCA) system and its validation over the Eastern Alpine region. Wea. Forecast. 26, 166-183. https://doi.org/10.1175/2010WAF2222451.1

Hanna, J. W., Schultz, D.M., and Irving, A. R., 2008: Cloud-Top Temperatures for Precipitating Winter Clouds. J. Appl. Meteor. Climatol. 47, 351-359. https://doi.org/10.1175/2007JAMC1549.1

Hortal, M., 2002: The development and testing of a new two-time-level semi-Lagrangian scheme (SETTLS) in the ECMWF forecast model. Quart. .J. Roy. Meteorol. Soc. 128, 1671-1687. https://doi.org/10.1002/qj.200212858314

Imrišek, M., Derková, M., and Janák, J., 2020: Estimation of GNSS tropospheric products and their meteorological exploitation in Slovakia. Cont. Geophys. Geodesy 50, 83-111. https://doi.org/10.31577/congeo.2020.50.1.5

Jurášek, M., Kaňák, J., Okon, L., Méri, L., 2017: Calibration and Monitoring of Slovak Weather Radar Network. Weather Radar Calibration and Monitoring workshop, 18-20 October, 2017, DWD, https://www.dwd.de/EN/specialusers/research_education/met_applications_specials/wxrcalmon 2017 presentations/poster_downloads/16_jurasek_wxrcalmon2017_poster.pdf?_blob=publicat ionFile \& $=2$

Kaňák, J., 2006: ViewMSG - An unconventional visualisation tool for MSG imagery. 2006 EUMETSAT Meteorological Satellite Conference, Helsinki, Finland. EUMETSAT Abstract brochure, 127, https://www.researchgate.net/publication/303975518_ViewMSG__An_unconventional_visualisation_tool_for_MSG_imagery

Kirkpatrick, C., McCaul, E. W. Jr., and Cohen, C., 2009: Variability of updraft and downdraft characteristics in a large parameter space study of convective storms. Mon. Weather Rev. 137, 1550-1561. https://doi.org/10.1175/2008MWR2703.1

Kokhanovsky, A., 2004: Optical properties of terrestrial clouds. Earth-Sci. Rev. 64, 189-241. https://doi.org/10.1016/S0012-8252(03)00042-4

Kox, L.G. and Ulbrich, U., 2015: Perception and use of uncertainty in severe weather warnings by emergency services in Germany. Atmos. Res. 158-159, 292-301. https://doi.org/10.1016/j.atmosres.2014.02.024

Leaflet, 2021: Website (visited on 7 May 2021).https://leafletjs.com/

Lopez, P., 2002: Implementation and validation of a new prognostic large-scale cloud and precipitation scheme for climate and data assimilation purposes. Quart. J. Roy. Meteor. Soc. 128, 229-257. https://doi.org/10.1256/00359000260498879

Lynch, P., Giard, D., and Ivanovici, V., 1997: Improving the Efficiency of a Digital Filtering Scheme for Diabatic Initialization. Mon. Weather Rev. 125, 1976-1982. https://doi.org/10.1175/1520-0493(1997)125<1976:ITEOAD>2.0.CO;2

Méri, L., Jurašek, M., Kaňák, J., and Okon, L., 2018: QUALITY-BASED RADAR DATA PROCESSING AND QPE AT THE SLOVAK HYDROMETEOROLOGICAL INSTITUTE. The 10th European Conference on Radar in Meteorology \& Hydrology ERAD Ede-Wageningen, The Netherlands. https://library.wur.nl/WebQuery/wurpubs/fulltext/454537 
Méri, L.; Gaál, L.; Bartok, J.; Gažák, M.; Gera, M.; Jurašek, M.; and Kelemen, M., 2021: Improved Radar Composites and Enhanced Value of Meteorological Radar Data Using Different Quality Indices. Sustainability 13, 5285. https://doi.org/10.3390/su13095285

Moller, A.R., Doswell, C.A. III, Foster, M.P., and Woodall, G.R., 1994: The operational recognition of supercell thunderstorm environments and storm structures. Wea. Forecast. 9, 327-347. https://doi.org/10.1175/1520-0434(1994)009<0327:TOROST>2.0.CO;2

Müller, M., Homleid, M., Ivarsson, K.-I., Køltzow, M.A., Lindskog, M., Midtbø, K.H., Andrae, U., Aspelien, T., Berggren, L., Bjørge, D., Dahlgren, P., Jørn Kristiansen, J., Randriamampianina, R., Ridal, M., and Vignes, $O$., 2017: AROME-MetCoOp: a nordic convective-scale operational weather prediction model. Weather Forecast 32, 609-627. https://doi.org/10.1175/WAF-D-16-0099.1

Noilhan, J. and Planton, S., 1989: A simple parameterization of land surface processes for meteorological models. Mon. Weather Rev., 117, 536-549. https://doi.org/10.1175/1520-0493(1989)117<0536:ASPOLS >2.0.CO;2

Novák, P., Kyznarová, H., and Fibich, O., 2019: Calibration and Monitoring of the Czech Weather Radar Network - Status Update 2019, 2nd Weather Radar Calibration \& Monitoring workshop (WXRCalMon), DWD, 30 October-01 November 2019, DWD, Presentation. https://www.dwd.de/EN/specialusers/research education/met applications specials/wxrcalmon 2019 presentations/presentation_downloads/06_czrad_wxrcalmon2019.pdf; jsessionid=5FE766 7701504FF420F2549A2110CD38.live21062? _ blob=-publicationFile\& $\mathrm{v}=2$

OMSZ, 2020: Időjárási napijelentés, 2020. június 8. Daily weather report of 8 June 2020, 133, OMSZ, Budapest. https://www.met.hu/idojaras/aktualis_idojaras/napijelentes/(in Hungarian)

Platt, C.M.R., 1997: A Parameterization of the Visible Extinction Coefficient of Ice Clouds in Terms of the Ice/Water Content. J. Atmos. Sci. 54, 2083-2098. https://doi.org/10.1175/1520-0469(1997)054<2083:APOTVE >2.0.CO;2

Seity, Y., Brousseau, P., Malardel, S., Hello, G., Bénard, P., Bouttier, F., Lac, C., and Masson, V, 2011: The AROME-France Convective-Scale Operational Model. Mon. Weather Rev. 139, 976-991. http://dx.doi.org/10.1175/2010MWR3425.1.

Simmons, A., J. and Burridge, D., M., 1981: An energy and angular-momentum conserving vertical finite-difference scheme and hybrid vertical coordinates. Mon. Wea. Rev. 109, 758-766. https://doi.org/10.1175/1520-0493(1981)109<0758:AEAAMC>2.0.CO;2.

Simon, A., Horváth, Á., Vivoda, J., 2006: Case study and numerical simulations of the November 19, 2004 severe windstorm in Central Europe. Idôjárás, 110, 91-123.

Sipos, Z., Simon, A., Csirmaz, K., Tünde, L., Mant,a R.-D., and Kocsis, Zs., 2021: A case study of a derecho storm in dry, high-shear environment. Időjárás 125, 1-37. https://doi.org/10.28974/idojaras.2021.1.1

Stoelinga, M. T., and Warner, T. T., 1999: Nonhydrostatic, mesobeta-scale model simulations of cloud ceiling and visibility for an East Coast winter precipitation event. J. Appl. Meteor. 38, 385-404. https://doi.org/10.1175/1520-0450(1999)038<0385:NMSMSO >2.0.CO;2

Sukoriansky, S., Galperin, B., and Staroselsky, I., 2005: A quasinormal scale elimination model of turbulent flows with stable stratification. Phys. Fluids 17, 085107. https://doi.org/10.1063/1.2009010.

Svoboda A. and Pekárová P., 1998. The catastrophic flood of July 1998 in the Malá Svinka catchment - its simulation. J. Hydrol. Hydromech., 46, 6, 356-365. (in Slovak)

Szintai, B., Szücs, M., Randriamampianina, R., and Kullmann, L., 2015: Application of the AROME non-hydrostatic model at the Hungarian Meteorological Service: physical parameterizations and ensemble forecasting, Idöjárás 119, 241-265.

Termonia, P., Fischer, C., Bazile, E., Bouyssel, F., Brožková, R., Bénard, P., Bochenek, B.,Degrauwe, D.,- Derková, M., El Khatib, R., Hamdi, R., Mašek, J., Pottier, P., Pristov, N. Seity, Y., Smolíková, P., Śpaniel, .O., Tudor, M., Wang, Y., Wittmann, C., and Joly, A., 2018: The ALADIN System and its Canonical Model Configurations AROME CY41T1 and ALARO CY40T1. Geosci. Model Dev. 11, 257-281. https://doi.org/10.5194/gmd-11-257-2018.

Trojáková, A., Mile, M. and Tudor, M., 2019: Observation Preprocessing System for RC LACE (OPLACE). Adv. Sci. Res. 16, 223-228.https://doi.org/10.5194/asr-16-223-2019.

Wang, Y., M. Belluš, A. Ehrlich, M. Mile, N. Pristov, P. Smolikova, O. Spaniel, A. Trojakova, R. Brozkova, J. Cedilnik, D. Klaric, T. Kovacic, J. Masek, F. Meier, B. Szintai, S. Tascu, J. Vivoda, C. Wastl, and Ch. Wittmann, 2017a: 27 years of Regional Co-operation for Limited Area Modelling in Central Europe (RC LACE), Bull. Amer. Met. Soc. 99, 1415-1432.

https://doi.org/10.1175/BAMS-D-16-0321.1 
Wang, Y., Meirold-Mautner, I., Kann, A., Slak, A. Š., Simon, A., Vivoda, J., Bica, B., Böcskör, E., Brezková, L., Dantinger, J., Giszterowicz, M., Heizler, G., Iwanski, R., Jachs, S., Bernard, T., Kršmanc, R., Merše, J., Micheletti, S., Schmid, F., Steininger, M., Haiden, T., Regec, A., Buzzi, M., Derková, M., Kozari'c, T., Qiu, X., Reyniers, M., Yang, J., Huang, Y., and Vadislavsky, E., 2017b: Integrating nowcasting with crisis management and risk prevention in a transnational and interdisciplinary framework. Meteorol. Zeits. 26, 459-473. https://doi.org/10.1127/metz/2017/0843

Wang, Y., Belluš, M., Wittmann, C., Steinheimer, M., Weidle, F., Kann, A., Ivatek-Šahdan, S., Tian, W., Ma, $X$., Tascu, S., and Bazile, E., 2011: The Central European limited-area ensemble forecasting system ALADIN-LAEF. Quart. J. Roy. Meteor. Soc. 137, 483-502. https://doi.org/10.1002/qj.751

Wang, Y., M. Belluš, F. Weidle, Wittmann, C., , Tang, J., Meier, F., Xia, F., and Keresturi, E., 2019: Impact of land surface stochastic physics in ALADIN-LAEF. Quart. J. Roy. Meteorol. Soc. 145, 1-19. https://doi.org/10.1002/qj.3623.

Wastl, C., Wang, Y., Atencia, A., Weidle, F., Wittmann, Ch., Zingerle, Ch., Keresturi, E., 2021: C-LAEF - Convection-permitting Limited Area Ensemble Forecasting System. Quart. J. Roy. Meteorol. Soc. 147, 1431-1451. https://doi.org/10.1002/qj.3986.

Weisman, M.L. and Trapp, R. J., 2003: Low-level mesovortices within squall lines and bow echoes. Part I: Overview and sensitivity to environmental vertical wind shear. Mon. Weather Rev. 131, 27792803. https://doi.org/10.1175/1520-0493(2003)131<2779:LMWSLA>2.0.CO;2

Wikimedia maps, 2021: website (visited on 7 May 2021), https://www.mediawiki.org/wiki/Wikimedia_Maps

\section{ABBREVIATIONS}

A-LAEF

AGL

ALADIN
ALARO - Limited Area Ensemble Forecasting above ground level

Aire Limitée Adaptation dynamique et Développement InterNational

ALADIN-LAEF Aire Limitée Adaptation dynamique et Développement InterNational - Limited Area Ensemble Forecasting

ALARO ALadin - AROme

AMDAR Aircraft Meteorological Data Relay

AMV HRWIND Atmospheric Motion Vector High-Resolution WINDs

AROME

ARPEGE Applications of Research to Operations at MEsoscale

AWS

BLENDVAR Action de Recherche Petite Echelle Grande Echelle

BUFR

C-LAEF Automatic Weather Station

CANARI combination of DF blending step and 3D-Var configuration Binary Universal Form for the Representation of meteorological data

Convection-permitting - Limited Area Ensemble Forecasting Code for the Analysis Necessary for Arpege for its Rejects and its Initialization

CAPE Convective Available Potential Energy

CAPPI Constant Altitude Plan Position Indicator 


\begin{tabular}{|c|c|}
\hline CTB & Cloud top brightness temperature \\
\hline CTT & Cloud top temperature \\
\hline CHMI & Czech Hydrometeorological Institute \\
\hline CLI & Cloud ice \\
\hline CLW & Cloud liquid water \\
\hline Cmax & Column maximum (radar reflectivity data) \\
\hline COSMO & Consortium for Small Scale Modelling \\
\hline $\mathrm{DF}$ & Digital Filter \\
\hline ECMWF & European Centre for Medium-Range Weather Forecasts \\
\hline ECMWF ENS & $\begin{array}{l}\text { European Centre for Medium-Range Weather Forecasts } \\
\text { Ensemble Forecast }\end{array}$ \\
\hline ECMWF HPCF & ECMWF High-Performance Computing Facility \\
\hline EDA & Ensemble Data Assimilation \\
\hline EHS & Enhanced surveillance \\
\hline EMADDC & European Meteorological Aircraft Derived Data Center \\
\hline EPS & Ensemble Prediction System \\
\hline ESDA & Ensemble of Surface Data Assimilation \\
\hline ESTOFEX & European Storm Forecast Experiment \\
\hline ESWD & European Severe Weather Database \\
\hline EUMETSAT & $\begin{array}{l}\text { European Organisation for the Exploitation of Meteorological } \\
\text { Satellites }\end{array}$ \\
\hline FLOODMED & $\begin{array}{l}\text { Monitoring, forecasting and best practices for FLOOD } \\
\text { Mitigation and prevEntion in the CADSES region }\end{array}$ \\
\hline GEFS & Global Ensemble Forecast System \\
\hline GNSS & Global navigation satellite system \\
\hline GTS & Global Telecommunication System \\
\hline HARMONIE-AF & $\begin{array}{l}\text { HIRLAME-ALADIN Research on Mesoscale } \\
\text { Operational NWP in Euromed - AROME }\end{array}$ \\
\hline HPC & High-Performance Computing \\
\hline HY & hydrostatic \\
\hline ICI scheme & iterative centred implicit scheme \\
\hline INCA & Integrated Nowcasting through Comprehensive Analysis \\
\hline INCA-CE & $\begin{array}{l}\text { Integrated Nowcasting through Comprehensive Analysis for } \\
\text { the Central European area }\end{array}$ \\
\hline ISBA & Interactions between Soil, Biosphere, and Atmosphere \\
\hline LAM & Limited area model \\
\hline LBC & Lateral Boundary Conditions \\
\hline
\end{tabular}


METEOSAT

MD2

MODE-S

MP

MRAR

MSG

MVS

$\mathrm{NH}$

NHHY

NMS

NWP

OI

OMSZ

OPERA OIFS

OPLACE

PPI

QNSE

RC LACE

RSS

SBCAPE

SI scheme

SETTLS

SHMÚ

SYNOP

TEMP

TKE

WER

ZTD

3D-Var

3MT package

4D-Var meteorological satellites operated by EUMETSAT

So-called Model II turbulence parameterization in Ďurán et al., 2014

Secondary Surveillance Radar Mode-Selective data

multi-physics

Meteorological routine air report

Meteosat Third Generation

Mesocyclonic Vorticity Signature

Non-hydrostatic

name of innovative formulation of linear operator used in semiimplicit time stepping (to be published)

National Meteorological Service

Numerical Weather Prediction

Optimal Interpolation

Országos Meteorológiai Szolgálat (Hungarian Meteorological Service)

Operational Program on the Exchange of Weather Radar Information Internet File System

Observation Preprocessing System for RC LACE

Plan Position Indicator

Quasi-Normal Scale Elimination

Regional Cooperation for numerical weather modeling on

Limited Area in Central Europe

Rapid Scanning Service

Surface-Based Convective Available Potential Energy

semi-implicit scheme

Stable extrapolation of two time level scheme

Slovak Hydrometeorological Institute

surface synoptic observations

upper air soundings

Turbulence Kinetic Energy

Weak Echo Region

Zenith Total Delay

Three-dimensional Variational data analysis

Modular Multi-scale Microphysics and Transport

Four-dimensional Variational data analysis 